\title{
COMMENTS
}

\section{THE STATUS OF MULTIEMPLOYER BARGAINING UNDER THE NATIONAL LABOR RELATIONS ACT}

\begin{abstract}
The recent decision of the National Labor Relations Board in Evening News Ass'n permitting unions as well as employers to withdraw unliaterally from established multiemployer bargaining units may well have jeopardized the utility of such units as a stabilizing force in labor relations. This comment examines the past and present policies of the NLRB with regard to multiemployer collective bargaining and attempts to demonstrate that the Board's conclusion in Evening News is neither dictated by precedent nor based on. sound policy considerations.
\end{abstract}

M ULTIEMPLOYER bargaining ${ }^{1}$ has generally been credited with promoting increased stability in collective bargaining relationships, ${ }^{2}$

\footnotetext{
'Generally the term "multiemployer bargaining" refers "to all situations in which two or more independent employers bargain or negotiate jointly, through an agent, committee or association, with one or more labor organizations representing employees of the several employers, with respect to wages, hours and other terms and conditions of employment." Rains, Legal Aspects and Problems of Multiemployer Bargaining, 34 B.U.I. REv. 159, 160 (1954).

Although multiemployer bargaining may be of "almost every conceivable size, shape, and character," there are basically two forms: (1) industrial, where a number of employers in the same industry join together for bargaining purposes, usually with the same union, and (2) geographical, where employers from the same area, though not necessarily from the same industry, bargain together. See Rains, supra at 160-61.

Geographically, multiemployer bargaining is typically divided into three major subgroups: nation-wide, region-wide, and city-wide or local-area. See Pierson, Prospects for Industry-Wide Bargaining, 3 IND. \& LAB. REL. REv. 341, 347 (1950). Multiemployer bargaining is probably most common on a city-wide or local-area basis. See U.S. Bureau of Labor Statistics, Collective Bargaining with Associations and Groups of Employets, in Industry-Wme Collective Bargaining: Promise or Menace 6 (Warne ed. 1950). True industry-wide bargaining appears to be relatively rare. See Lester, Reflections on the "Labor Monopoly" Issue, in id. at 30.

See generally Pierson, MUlti-Employer Bargaining: Nature and Scope 1-26 (1948); Steele, The Impact of Multi-Unit Bargaining on Industrial Relations, 20 So. ECON. J. 130-31 (1953).

2 See NLRB v. Local 499, Teamsters Union, 353 U.S. 87, 94-95 (1957); GeneraL Subcomm. ON Labor, House CoMm. ON EdUcation and Labor, 88Th CoNG., 2d Sess., MUltiemployer Association Bargaining and its Impact on tHe Collegtive Bargaining Process 32 (Comm. Print 1964); Slate, Trade Union Behavior and the Local Employers' Association, 11 IND. \& LAB. REL. REv. 42 (1957); Steele, supra note 1, at 133-36; Witte, Eeonomic Aspects of Industry-Wide Collective Bargaining, in INDUSTRY-WIDE CoLIECTVE Bargaining: Promise or Menace 51 (Warne ed. 1950). See generally Feinsinger, Collective Bargaining in the Trucking Industry (1949); KerR \& RANDall, Col-
} 
particularly in those industries and localities characterized by a large number of relatively small, highly competitive businesses. ${ }^{3}$ Negotiating as a group, employers are in a better position to match the strength of organized labor by presenting a united front to union demands $s^{4}$ and utilizing the defensive lockout to counter union

Lective Bargaining in the Pacific Coast Pulp and Paper Industry (1948); Somers, The Multiemployer Proposals and the Coal Operators, 6 LAB. L.J. 296 (1955).

Critics of multiemployer bargaining do not deny that it leads to increased stability in bargaining relations but question the assumption that "any policy which lays claims to promoting stability" is necessarily good or correct. See Wolman, IndustryWide Bargaining, in Industry-Wide Collectrve Bargaining: Promise or Menace 14 (Warne ed. 1950). See generally Van Sickle, Industry-Wide Collective Bagaining, in id. at 42; Wolman, Industry-Wide Bargaining, 1 LAB. L.J 167 (1949). These critics argue that whatever is gained in the way of increased stability is more than offset by the harm to the national economy resulting from "taking wages out of competition" and vesting in union leaders "monopolistic powers." See Snavely, The Impact of Multi-Unit Bargaining on the Economy, 19 So. EcoN. J. 445, 452-57 (1953). It has been suggested that increases in wages can be more easily passed on to the public through multiemployer bargaining. See FIsHer, Collective Bargaining in the BITUMINous CoAl INDUSTRY: AN APPRAISAl 42 (1948). Uniform wage rates achieved by means of multiemployer contracts also tend to reduce the mobility of labor. See McCaffree, Regional Labor Agreements in the Construction Industry, 9 IND. \& LAB. REL. REv. 595, 607 (I956); Snavely, supra at 452. Other arguments against multiemployer bargaining are that it creates the potential for crippling strikes, leads to "collusion" between management and labor, and impedes teclmological change. See Snavely, supra at 453.57 .

It would appear unsound, however, to criticize the practice of multiemployer bargaining as a whole. Although wage uniformity appears to be the focus of the criticisms directed at group bargaining, there are variety of types of uniformity and the different economic effects produced thereby will cause the desirability of multiemployer bargaining to vary accordingly. See KenNedy, The Significance of WAgE UNIFORMITY $39-40$ (1949). Moreover, cases of true industry-wide bargaining, at which most of the criticism has been aimed, are relatively rare. See note 1 supra. Furthermore, wage rates do not appear to have risen more rapidly under multiemployer than single employer bargaining. See Lester \& Robie, Wages Under National and Regional Collective Bargaining: Experience in Seven Industries, in INDUSTRY-WIDE CoLLective Bargaining: Promise or Menace 90-91 (Warne ed. 1950).

${ }^{8}$ Multiemployer bargaining is most prevalent among relatively small producers. See U.S. Bureau of Labor Statistics, supra note 1, at 7-8. Recent surveys indicate that in such industries as clothing, construction, hotel, longshoring, maritime, trucking and warehousing, eighty to ninety percent of all unionized workers are covered by multiemployer contracts. In the baking, printing, canning and textile industries from sixty to eighty per cent are covered by such contracts. 1961 figures cited in GeNERAL SUBCOMM. ON LABOR, op. cit. supra note 3, at 6. Large corporations generally oppose and do not participate in multiemployer bargaining. See statements by industry representatives, in Industry-Wide Collective Bargaining: Promise or Menace 94-I06 (Warne ed. 1950). Few examples of multiemployer bargaining, therefore, occur in the mass production industries. See U.S. Bureau of Labor Statistics, supra note 1, at 6. See generally Pierson, Multi-Employer Bargaining: NATURE ANd SCOPE (1948); Chamberlain, The Structure of Bargaining Units in the United States, 10 IND. \& LAB. REL. REv. 3 (1956).

- See Garret \& Tripp, Management Problems Implicit in Multi-EMployer BarGAINING 3 (1949); KERR \& RANDALL, op. cit. supra note 2, at 3; Slate, supra note 2, at 
"whipsaw" strike tactics. ${ }^{5}$ Despite the advantage of multiemployer bargaining to employers in terms of increased bargaining power, unions generally favor such bargaining. ${ }^{6}$ Through the multiemployer device they gain not only the additional security inherent in the multiemployer unit, ${ }^{7}$ but also a greater standardization of wages and working conditions as a result of the group contract. ${ }^{8}$

46-48; Somers, Pressure on an Employers Association in Collective Bargaining, 6 IND. \&. LAB. REL. REv. 557, 568 (1953); Steele, supra note 1, at 133-34.

Other factors, of course, may influence the decision of a group of employers to bargain on a multiemployer basis. In those industries faced with cutthroat competition and in which labor constitutes a significant part of total production costs, employers may desire to take wages out of competition. See FEINSINGER, op. cit. supra note 2, at 31; Seybotd, The Philaderphin Printing Industry: A Case Study 15 (1949); Steele, supra note 1, at 357. Small employers may also bargain together to prevent tbe level of wages in the industry from being set by a few large companies. See ABERSOLd, Problems of HoURLY RATE UNIFoRMtry 20 (1949). Finally, multiemployer bargaining may be particularly beneficial to employers in industries where employees change employers on a daily, weekly, or job basis and hiring is conducted through a union hiring hall. See Evening News Ass'n, 1965 CCH NLRB 16462, 16469 (dissenting opinion). See generally SEYBotD, op. cit. supra; McCaffree, supra note 2.

s "Whipsawing" is the term used to describe the union tactic of exerting strike pressure against only one of a group of employers at a time in order to cause successive individual employer capitulations. The union, subsidized by its nonstriking members, is in a position to hold out for a considerable period of time while the struck employer is under substantial pressure to surrender to union demands. By being shut down while his competitors continue to operate, the struck employer is threatened with serious market loss, but perbaps more important is his knowledge that if he settles on union terms his competitors via the "whipsaw" process will eventually accede to the same terms. Thus, faced with market losses if he does not surrender to union demands and the prospect that if he does settle he will be at no competitive disadvantage, the struck employer frequently agrees to union terms. It is often, therefore, only a matter of time before the union through this "chipping away" or "playing off" process is able to impose its demands upon all of the employers in the group. See Brundage, The Lockout and Multi-Employer Bargaining, 14 LAB. L.J. 976, 977 (1963); Note, 66 Harv. L. Rev. 886, 895 (1953); Note, 3 Stan. L. Rev. 510 (1951). For a discussion of the employers' right to lockout to counter union "whipsaw" tactics, see notes 145-66 infra and accompanying text.

- See statements by representatives of organized labor, in INDUSTRY-WidE COLlective Bargaining: Promise or Menace 67-83 (Warne ed. 1950); notes 7-8, 10.11 infra and accompanying text. See generally Twentieth Century Fund, Labor and Management Look at Collective Bargaining: $A$ Canvass of Leaders' Views, in INDUSTRY-WIDE COLlective Bargaining: Promise or Menace 106.11 (Warne ed. 1950).

'Multiemployer bargaining reduces raiding, since a rival union must win over a much larger number of employees in order to replace the incumbent union. In addition, it also reduces friction within the incumbent union. By promoting standardized conditions it lessens the possibility that rival union leaders will seize upon differentials as a "cause for agitation and means of political advancement." See Steele, supra note 1 , at 135. See generally KERR \& RANDALL, op. cit. supra note 2, at 9-10, 28.

${ }^{8}$ The goal of most unions is to achieve uniform pay scales within the various plants that they represent in order to satisfy "the equation of equal pay for equal work." See ABErsold, op. cit. supra note 4, at 5.6; Witte, supra note 2, at 50. Not only does the satisfaction of this equation lead to a contented membership (see note 7 supra), but once an industry is completely organized by a single union, the threat of competi- 
Finally, there are economic advantages of group bargaining common to both employers and unions. By negotiating a single contract rather than many, employers may pool their resources and consequently are often able to afford the services of a highly skilled, professional negotiator, ${ }^{9}$ while unions are able to save the expense and time involved to negotiate separate contracts with each employer. ${ }^{10}$ Moreover, welfare benefits such as pension plans, medical payments, and unemployment compensation, as well as industry-wide apprenticeship and training programs which would ordinarily be beyond the capabilities of a single employer may be desirable byproducts of bargaining on a multiemployer basis. ${ }^{11}$

Whether multiemployer bargaining will continue to be a stabilizing force in labor relations has been seriously questioned ${ }^{12}$ in view of the decision by the National Labor Relations Board in Evening News $A s s^{\prime} n,{ }^{13}$ which permits unions to withdraw unilaterally from existing multiemployer bargaining units. At least one commentator feels that this decision "may well augur a complete upheaval in multiemployer bargaining."14 Against this background of uncertainty concerning the future of group bargaining, this comment will examine the authority of the NLRB to certify multiemployer units, the criteria utilized to determine if a particular unit is appropriate, the rules governing withdrawal from multiemployer units, and the impact of the Evening News decision.

tion from nonunion plants is removed. The union, therefore, no longer need worry about nonunion plants underselling and taking away the markets of union operations, nor about being "played off" by one employer against another with resulting wage cuts. See FISHER, op. cit. supra note 2, at 42; GENERAL SUBCOMM. on LABOR, op. cit. supra note 2, at 10. Moreover, the employers' will to resist union demands is considerably weakened, since the increased costs occasioned by such demands can more easily be passed on to the consumer. FisHer, op. cit. supra note 2, at 42 . See generally GARRET \& TRIPP, op. cit. supra note 4, at 14; McCaffree, supra note 2, at 605; Steele, supra note 1 , at 134 .

- See McCaffree, supra note 2, at 606; Slate, supra note 2, at 48; Steele, supra note 1, at 137 .

${ }^{10}$ See id. at 137-38. See generally GaRRET \& TRIPP, op. cit. supra note 4, at 2-3; KERR \&: RANDALL, op. cit. supra note 2, at 8-10; McCaffree, supra note 2, at 604.

11 See General Subcomm. on LABor, op. cit. supra note 2, at 15; Steele, supra note 1 , at 139 .

12 See 1966 A.B.A. LABOR RELATIONS SEction 423-24; 41 N.Y.U.L. REv. 651, 652 (1966); 44 Texas L. REv. 1047, 1050 (1966).

181965 CCF NLRB 16462, enforced sub nom. Detroit Newspaper Publishers Ass'n v. NLRB, 372 F.2d 569 (6th Cir. 1967), 41 N.Y.U.L. REv. 651 (1966), 44 TEXAs L. REv. 1047 (1966).

241966 A.B.A. Labor ReLations Section 423. 
Authority of The NLRB to Find Multiemployer

UNITS APPROPRIATE

Section 9 (b) of the National Labor Relations Act requires that the NLRB "decide in each case whether . . . the unit appropriate for the purposes of collective bargaining shall be the employer unit, craft unit, plant unit or subdivision thereof . . ."15 As early as 1938 the Board was confronted with the question whether section 9 (b) permits finding a multiemployer unit "appropriate." Although the broadest unit expressly mentioned therein is that of "employer," the Board in Shipowners' Ass' $n^{16}$ read section 9 (b) in conjunction with section 2(2),17 which defined "employer" as including "any person acting in the interest of the employer," and section $2(1),{ }^{18}$ which included "associations" within the definition of "persons," and concluded that a multiemployer unit was appropriate where prior bargaining had been conducted on a group basis. In a later case the Board reasoned that a narrower construction of section 9 (b) would compel it to certify single employer units

in conflict with existing practices of collective bargaining which are satisfactory to the employers and to ... the employees involved [and thereby] ... disrupt and possibly destroy that stability in employment relations which it was the very purpose of the Act to foster. ${ }^{19}$

Only recently has this interpretation of the statute been passed upon by a reviewing court, ${ }^{20}$ although on occasion a court had either ex-

${ }^{18} 61$ Stat. 143 (1947), 29 U.S.C. $\$ 159$ (b) (1964).

10 7 N.L.R.B. 1002 (1938), appeal dismissed sub nom. AFL v. NLRB, 103 F.2d 933 (D.C. Cir. 1939), aff'd, 308 U.S. 401 (1940). See note 36 infra and accompanying text. ${ }^{27} 49$ Stat. 450 (1935), as amended, 61 Stat. 137 (1947), 29 U.S.C. $\$ 152$ (2) (1964). The definition of "employer" in $\$ 2(2)$ was amended by the Taft-Hartley Act to read "any person acting as an agent of an employer, directly or indirectly." (Emphasis added.) This change, however, had no effect on the Board's interpretation that the statute permits certification of multiemployer units. After the passage of the amend. ment, the Board held that an "exhaustive search and study of the legislative history of the Act, as amended, fails to reveal an intent by Congress to limit the appropriate unit . . to a single employer unit." Furniture Firms of Duluth, 81 N.L.R.B. 1318, 1320 (1949).

${ }_{28} 49$ Stat. 450 (1935), as amended, 61 Stat. 137 (1947), 29 U.S.C. $\$ 152$ (1) (1964).

${ }^{10}$ Waterfront Employers Ass'n, 71 N.L.R.B. 80, 110 (1946).

${ }^{20}$ The dearth of appellate court holdings concerning the statutory authority of the NLRB to certify multiemployer bargaining units stems in part from the difficulty of obtaining judicial review of a Board unit determination. Section $10(f)$ of the NLRA, provides for review by the courts of appeals only of "final orders" of the Board. 61 Stat. 148 (1947), 29 U.S.C. $§ 160$ (f) (1964). Bargaining unit determinations, however, 
pressly ${ }^{21}$ or tacitly indicated its approval of the Board's established practice of certifying multiemployer units. ${ }^{22}$ In $N L R B v$. Checker Cab Co. ${ }^{23}$ the Sixth Circuit unanimously upheld the Board's reading of the act "as granting power to the NLRB to hold independent employers ... to be joint employers for the purpose of defining an appropriate unit."24

are not "final orders" within the meaning of that section. AFL v. NLRB, 308 U.S. 401 (1940). Consequently, they are reviewable only when the Board petitions a court of appeals under $\$ 10$ (e) for enforcement of its order to bargain in the unit which it has found appropriate. 61 Stat. 147 (1947), 29 U.S.C. $\$ 160$ (e) (1964). The reason Congress so severely limited court interference in representation matters was to prevent "dilatory tactics" aimed at delaying collective bargaining. See Boire v. Miami Herald Publishing Co., 343 F.2d 17, 20 (5th Cir. 1965).

Recognizing this congressional purpose, the federal district courts have restricted the use of their equity porvers to enjoin representation proceedings to three narrow situations: (1) where the suit involves "public questions particularly high in the scale of our national interest because of their international complexion," McCulloch v. Sociedad National de Marineros de Honduras, 372 U.S. 10, 17 (1963); (2) where there is a substantial showing that Board action has violated the constitutional rights of the complaining party, Fay v. Douds, 172 F.2d 720, 725 (2d Cir. 1949); and (3) where the Board has clearly acted "in excess of its delegated powers and contrary to a specific prohibition in the Act." Leedom v. Kyne, 358 U.S. 184, 188 (1958). The third exception has been confined to cases where there has been a "plain" violation of an unambiguous provision of the act. See, e.g., Eastern Greyhound Lines v. Fusco, 323 F.2d 477 (6th Cir. 1963); International Ass'n of Tool Craftsmen v. Leedom, 276 F.2d 514 (D.C. Cir. 1960); Consolidated Edison Co. v. McLeod, 202 F. Supp. 351 (S.D.N.Y.), aff'd, 302 F.2d 354 (2d Cir. 1962). See generally note 35 infra.

${ }_{21}$ See, e.g., NLRB v. Local 449, Teamsters Union, 353 U.S. 87, 95 (1957), where the Supreme Court indicated that in its view the failure of Congress to enact proposals to limit or outlaw multiemployer bargaining at the time of the Taft-Hartley Act (see note 19 supra) demonstrates that Congress intended "that the Board should continue its ... practice of certifying multiemployer units ...." See also NLRB v. Lund, 103 F.2d 815, 819 (8th Cir. 1939), where the court stated that "it can make no difference in determining what constitutes an appropriate unit for collective bargaining whether there be two employers of one group of employees or one employer of two groups of employees."

22 Various courts have enforced bargaining orders based on multiemployer unit determinations without questioning the Board's authority under the act to find such units appropriate. E.g., Universal Insulation Corp. v. NLRB, 361 F.2d 406 (6th Cir. 1966), enforcing 149 N.L.R.B. 1397 (1964); NLRB v. Sheridan Creations, Inc., 357 F.2d 245 (2d Cir. 1966), enforcing 148 N.L.R.B. 1503 (1964); NLRB v. Jeffries Banknote Co., 281 F.2d 893 (9th Cir. 1960), enforcing sub nom. Anderson Lithograph Co., 124 N.L.R.B. 920 (1959). See also AFL v. NLRB, 308 U.S. 401 (1940), affirming 103 F.2d 933 (D.C. Cir. 1939), dismissing appeal sub nom. Shipowners' Ass'n, 7 N.L.R.B. 1002 (1938).

${ }^{23} 367$ F.2d 692 (6th Cir. 1966), enforcing 14 I N.L.R.B. 583 (1963).

$24367 \mathrm{~F} .2 \mathrm{~d}$ at 698 . The court's decision in Checker $\mathrm{Cab}$ was not surprising. During congressional consideration of the Taft-Hartley amendments, a proposal to prohibit competing employers from engaging in multiemployer bargaining unless all plants involved were less than fifty miles apart and employed less than one hundred persons was narrowly defeated in the Senate by a vote of 44 to 43 . See NLRB, LegisLative History of the Labor Management Relations ACt, 1947, 1298-1302 (1948). This defeat was later interpreted by the Supreme Court as indicating congressional approval 
Although the administrative criteria utilized by the Board to determine the appropriateness of a multiemployer unit generally require that multiemployer bargaining be initiated voluntarily, ${ }^{2-\bar{v}}$ its authority under the act is not conditioned upon the consent of the parties. In Waterfront Employers $A s^{\prime} n^{26}$ the Board, declaring again that it was empowered to find multiemployer units appropriate, stated that it was "not persuaded otherwise by the fact that the companies and employer associations have indicated that they do not desire multiple-employer units." 27 The Board reasoned that to hold that it was prevented by employer opposition from finding a multiemployer unit appropriate would permit employers to shape the bargaining unit at will, thus vesting in "the employers rather than the Board the power to determine the appropriate unit." 28 Perhaps the same reasoning underlies the Board's decision in Stouffer Corp., ${ }^{29}$ which held that a multiemployer unit was appropriate despite the petitioning union's desire to bargain on a single employer basis.

Similarly, the Board has not hesitated to find single employer units appropriate even though both the employers and a union desired a multiemployer unit. ${ }^{30}$ To permit mutual consent to be determinative of the scope of the bargaining unit, especially in those instances in which one union seeks a multiemployer unit and another seeks single employer units, would again permit the employers rather than the Board to determine the appropriate bargaining unit.

of the Board's practice to certify multiemployer units. See NLRB v. Local 449, Teamsters Union, 353 U.S. 87, 96 (1957).

The only opinion to question the Board's authority to certify multiemployer units is that of Member Styles dissenting in Continental Baking Co., 99 N.L.R.B. 777, 784 (1952). Styles reasoned that inasmuch as $\$ 9(\mathrm{~b})$ does not expressly authorize the Board to establish a bargaining unit broader than that of a single employer, the Board's practice could only be supported on the ground that multiemployer units are based on the mutual consent of the parties. Id. at 788. This view has never been accepted by a majority of the Board and would appear erroneous in light of those cases in which the Board has found a multiemployer unit appropriate over the objection of one of the parties. E.g., Quality Limestone Prods., Inc., 143 N.L.R.B. 589 (1963); Checker Cab Co., supra note 23; Stouffer Corp., 10I N.L.R.B. 1331 (1952); Johnson Optical Co., 85 N.L.R.B. 895, amended, 87 N.L.R.B. 539 (1949); Waterfront Employers Ass'n, 7 I N.L.R.B. 80 (1946).

${ }^{25}$ See notes $42-67$ infra and accompanying text.

207 I N.L.R.B. 80 (1946).

22 Id. at 111 .

${ }^{28}$ Ibid.

20 IOI N.L.R.B. 1331 (1952).

${ }^{80}$ E.g., Shreveport-Bossier Cleaners \& Laundries, Inc., 124 N.L.R.B. 534 (1959); Crucible Steel Castings Co., 90 N.L.R.B. 1843 (1950). 
However, in those cases in which only one union is involved or all the unions involved are in agreement as to the scope of the unit, the Board has usually found appropriate the unit desired by the parties. ${ }^{31}$ Even in this limited situation the Board has indicated that it is not abdicating to the parties its authority under the act to determine the appropriate unit. ${ }^{32}$ Rather, "the very fact that there is no dispute of itself usually indicates that the proposed unit is appropriate, and consequently in such cases the Board's unit finding customarily coincides with that sought." 33

\section{Criteria Employed by the NLRB to Find Multiemployer UNITS APPROPRIATE}

Since the Board has the authority under section 9 (b) to certify multiemployer bargaining units, ${ }^{34}$ the formulation of the criteria for finding such units appropriate falls within its wide administrative discretion..$^{35}$ Exercising this discretion for the first time in 1938 in Shipowners' $A s s^{\prime} n^{36}$ the Board relied primarily on the fact that the employers involved had traditionally bargained with the incumbent

${ }^{31}$ E.g., Rose Exterminator Co., 143 N.L.R.B. 59 (1963); Alliance of Television Film Producers, Inc., 126 N.L.R.B. 54 (1960); Broward County Launderers \& Cleaners Ass'n, 125 N.L.R.B. 256 (1959); Calumet Contractors Ass'n, 121 N.L.R.B. 80 (1958).

${ }^{32}$ See 8 NLRB ANN. REP. 53-54 (1943).

${ }^{38}$ Id. at 54. (Emphasis added.)

34 See notes 15-24 supra and accompanying text.

as The NLRB has broad discretionary powers to determine the appropriate bargaining unit, since no detailed criteria are specified by any absolute rule in the statute. Packard Motor Car Co. v. NLRB, 330 U.S. 485 (1947). Congress, aware of the need for flexibility in the determination of the appropriate unit, provided only "that the selection be made so as to insure to employees the full benefit of their right to selforganization and to collective bargaining, and otherwise to effectuate the policies of the Act . . . ." Id. at 491. Thus, it is well settled that the courts will not substitute their judgment for that of the Board and overturn a Board bargaining unit determination unless it appears to be arbitrary or capricious. E.g., Packard Motor Co. v. NLRB, supra; Pittsburgh Plate Glass Co. v. NLRB, 313 U.S. 146 (1941); NLRB v. Quaker City Life Ins. Co., 319 F.2d 690 (4th Cir. 1963); NLRB v. Smythe, 212 F.2d 664 (5th Cir. 1954); NLRB v. Lettie Lee, Inc., 140 F.2d 243 (9th Cir. 1944). See generally note 20 supra.

${ }^{38} 7$ N.L.R.B. 1002 (1938), appeal dismissed sub nom. AFL v. NLRB, 103 F.2d 933 (D.C. Cir. 1939), aff'd, 308 U.S. 401 (1940). See notes 16-19 supra and accompanying text. In Shipowners' Ass'n the Board found that all "the workers who do the longshore work in the Pacific Coast ports of the United States for the conpanies which are members of [the employer associations involved] . . . constitute a unit appropriate for the purposes of collective bargaining ..." 7 N.L.R.B. at 1025. In a later case, however, the Board recognized that it had overlooked three "exception ports" which were separately represented at the time it found the coast-wide unit appropriate and granted the workers in those ports the opportunity to choose by secret ballot whether they desired to be represented in the coast-wide unit. Shipowners' Ass'n, 32 N.L.R.B. 669, 683 (1941). 
union on a group basis through an elaborate and formal organization to which they had delegated broad authority to act in nearly all matters usually regarded as within the scope of collective bargaining. For several years thereafter the Board refused to find a multiemployer unit appropriate unless the employers had actually delegated to their association or common bargaining representative the authority to enter into binding collective bargaining agreements ${ }^{37}$ and had actually bargained as a group in the past. ${ }^{38}$

The evolutionary development of the present Board criteria began in 1943. First, the Board in Rayonier, Inc.,39 abandoned the actual delegation of authority requirement, at least where the employers were members of an association, and took the more realistic approach that a multiemployer unit was appropriate where employers had bargained as a group for many years and had by "customary adherence to . . . uniform labor agreements ... demonstrated their desire to be bound by group rather than by individual action." 40 Next the Board abandoned its bargaining history requirement as well. In George F. Carleton of Co. ${ }^{.11}$ it held that three nonmember employers who had indicated their desire to bargain in a multiemployer unit with the members of an employers' association could properly be included in an appropriate multiemployer unit, even though they were not members of the association, had not delegated to the association the authority to bind them to a group contract, and had not previously participated in group negotiations. Thus, at this juncture a group of employers could determine the appropriateness of a multiemployer unit simply by manifesting a

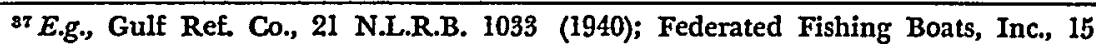
N.L.R.B. I080 (1939); Trawler Maris Stella, Inc., 12 N.L.R.B. 415, 424-25 (1939); Monon Stone Co., 10 N.L.R.B. 64, $71-73$ (1938), amended, II N.L.R.B. 14 (1939). But see Stevens Coal Co., 19 N.L.R.B. 98, 106-09 (1940). Even where the employers had bargained as an association, the Board would not find a multiemployer unit appropriate unless the employers had actually delegated to the association the authority to enter into binding collective bargaining agreements on their behalf. E.g., Sagamore Mfg. Co., 39 N.L.R.B. 909, 916 (1942), overruled on other grounds, Luther Mfg. Co., 61 N.L.R.B. 858, 864 (1945); Aluminum Line, 8 N.L.R.B. 1325, 1341, amended, 9 N.L.R.B. 72 (1938).

${ }^{38}$ Even a formal association with binding authority would not suffice to make a multiemployer unit appropriate in the absence of a history of actual bargaining on a group basis, e.g., Pacific American Fisheries, Inc., 28 N.L.R.B. 244 (1940), unless the employers and unions involved stipulated that such a unit was proper, e.g., Brenizer Trucking Co., 44 N.L.R.B. 810 (1942).

so 52 N.L.R.B. 1269, 1274 (1943).

10 Id. at $1274-75$.

154 N.L.R.B. 222 (1943). 
willingness to bargain as a group and to be bound by the resulting contract.

The weakness of the Carleton test is readily apparent: it gave to the employers the ability to determine the appropriate bargaining unit notwithstanding disagreement by rival unions as to the scope of the unit. Perhaps for this reason the Carleton test was expressly overruled two years later in Advance Tanning Co. ${ }^{42}$ where the Board held that nonmembers of an employers' association could not be included in an appropriate multiemployer unit unless they had in fact participated in joint negotiations. This principle was reaffirmed in Associated Shoe Industries, Inc., ${ }^{43}$ where the Board stated that

the essential element ... for establishing a multiemployer unit is participation by a group of employers, whether members or nonmembers of an association, either personally or through an authorized representative, in joint bargaining negotiations. ${ }^{44}$

Thus, today the general rule is that a single employer unit is presumptively appropriate, ${ }^{45}$ and a multiemployer unit is appropriate only where there has been a substantial history of bargaining on a multiemployer basis indicating an unequivocal intent to be bound by group rather than individual action. ${ }^{46}$ Despite the absence of

$\therefore 60$ N.L.R.B. 923, 931 n.14 (1945). Prior to Carleton the Board had been careful not to vest in either the employers or the union the power to determine the appropriate bargaining unit. See notes 26-31 supra and accompanying text.

43 81 N.L.R.B. 224 (1949).

«Id. at 229.

¿E.g., Cab Operating Corp., 1965 CCH NLRB 15974; Carbondale Retail Druggists Ass'n, 131 N.L.R.B. 1021 (1961); John Breuner Co., 129 N.L.R.B. 394 (1960); Schaeffers Prospect IGA Store, 124 N.L.R.B. 1433 (1959); Arden Farms, 117 N.L.R.B. 318, aff'd, 118 N.L.R.B. 117 (1957); Jacob Schmidt Brewing Co., 93 N.L.R.B. 738 (1951); Columbia Marble Co., 89 N.L.R.B. 1482 (1950).

"A substantial multiemployer bargaining history has been defined as actual participation by the employers or their authorized representatives in group negotiations, e.g., Morgan Linen Service, Inc., 131 N.L.R.B. 420 (1961); Columbia Marble Co., 89 N.L.R.B. 1482 (1950); Morley Mfg. Co., 83 N.L.R.B. 404 (1949), which unequivocally manifests their intent to be bound by group rather than individual action, e.g., Quality Limestone Prods., Inc., 143 N.L.R.B. 589 (1963); Chicago Metropolitan Home Builders Ass'n, 119 N.L.R.B. 1184 (1957), for a period of time usually exceeding one year, see, e.g., Miron Bldg. Prods. Co., 116 N.L.R.B. 1406 (1956); Van Iderstine Co., 95 N.L.R.B. 966 (195I); Jerry Fairbanks, Inc., 93 N.L.R.B. 898 (1951). It is essential that such a bargaining history involve the same employers and union. E.g., Chicago Metropolitan Home Builders Ass'n, supra; Bull Insular Lines, Inc., 107 N.I.R.B. 674 (1954).

If a sufficient history of group bargaining exists, a multiemployer unit will be found appropriate even though the employers are in a different line of business or the employees in the proposed unit have diverse skills. E.g., Safeway Stores, 
any formal organization or delegation of authority, if joint bargaining sessions have repeatedly resulted in the negotiation of collective bargaining agreements, a multiemployer unit is deemed appropriate. ${ }^{47}$ However, an actual history of multiemployer bargaining is a prerequisite to finding such a unit appropriate. Therefore, although a group of employers make joint decisions on labor relations $^{48}$ or sign identical bargaining agreements, ${ }^{48}$ unless they have actually negotiated on a group basis the Board will not find a multiemployer unit appropriate..$^{58}$

There are, however, two exceptions to the general rule requiring a multiemployer bargaining history: (1) where all the parties involved agree that a multiemployer unit is appropriate, ${ }^{51}$ and (2) where there exists common control of separate companies so that for purposes of labor relations they are deemed to constitute a single

Inc., 98 N.L.R.B. 528 (1952); Cloth Laying Appliances Co., 78 N.L.R.B. 785 (1948). But see Columbia Marble Co., supra. Furthermore, neither fluctuating membership of the employer group nor the retention by the participating employers of the right to approve or disapprove any agreement will preclude finding a multiemployer unit appropriate if a sufficient bargaining history exists. Quality Limestone Prods., Inc., supra. On the other hand, an employer may be excluded from a multiemployer unit where the relationship with the employer association has been terminated by resignation or expulsion and the association refuses to represent the nonmember $\mathrm{em}$. ployer. Laundry Owners Ass'n, 123 N.L.R.B. 548 (1959).

"E.g., Atlas Shower Door Co., 181 N.L.R.B. 96 (1961); Belleville Employing Printers, 122 N.L.R.B. 350 (1958); Mohnelli, Santoni \& Freytes, 118 N.L.R.B. 1010 (1957); Charles H. Harper, 117 N.L.R.B. 1031 (1957); Balaban \& Katz, 87 N.L.R.B. 1071 (1949); Air Conditioning Co., 81 N.L.R.B. 946, 951 . (1949), supplementing 79 N.L.R.B. 1896 (1948).

48 E.g., Electric Theatre, 1966 CCH NLRB 25422; L. C. Beauchamp, 87 N.L.R.B. 23 (1949). Membership in an employer associatiou for the purpose of negotiating collective bargaining agreements is not sufficient to constitute an appropriate multiemployer unit, absent a history of actual bargaining on a group basis. E.g., Schaeffer Prospect IGA Store, 124 N.L.R.B. 1439 (1959); Morley Mfg. Co., 83 N.L.R.B. 404 (1949). Similarly, mere membership in a trade association for purposes other than collective bargaining is not deemed a multiemployer bargaining history. E.g., Hot Springs Bathhouse Ass'n, 133 N.I.R.B. 1066 (1961); Houston Auto. Dealers Ass'n, 182 N.L.R.B. 947 (1961).

${ }^{\circ}$ E.g., Chester County Beer Distribs. Ass'n, 133 N.L.R.B. 771 (1961); Texas Cartage Co., 122 N.L.R.B. 999 (1959); Plumbing Contractors Ass'n, 93 N.L.R.B. 1081 (1951); Morley Mfg. Co., supra note 48. However, the fact that the employers sign separate contracts will not preclude the appropriateness of a multiemployer unit if there is a history of actual bargaining on a group basis. E.g., Alton Ass'n of Petroleum Retailers, 124 N.L.R.B. 1213 (1959).

${ }^{50}$ E.g., Cab Operating Corp., 1965 CCF NLRB 15974; Shreveport-Bossier Cleaners 8. Laundries, Inc., 124 N.L.R.B. 534 (1959); Arden Farms, 117 N.L.R.B. 318, aff'd, 118 N.L.R.B. 117 (1957); Crucible Steel Castings Co., 90 N.L.R.B. 1843 (1950); Bear Creek Orchards, 87 N.L.R.B. 1348 (1949).

51 Cases cited note 31 supra. 
employer. ${ }^{52}$ Because the bargaining history requirement appears to have been formulated specifically to avoid vesting in the parties rather than the Board the power to decide disputed claims as to the scope of the appropriate bargaining unit, ${ }^{53}$ it is not surprising that the Board has held that when a group of employers and the union or unions involved desire a multiemployer unit, and no other party is seeking single employer units, "collective bargaining history is not prerequisite to finding the multiemployer unit appropriate." 54

A more abrupt departure from established criteria occurred in 1963 in Checker Cab Co.55 when the Board found appropriate a multiemployer unit of some 286 independently owned and operated taxicab companies despite the employers' objections and the fact that they had never before bargained as a group. In fact there had been no collective bargaining between the parties whatsoever. ${ }^{58}$ Nevertheless, because the operation of Checker Cabs had been represented to the public as a single business enterprise and the Checker organization was authorized by its member companies "to exercise a substantial degree of control over the drivers of each of its members," 57 the Board found Checker and its members "joint employers in a common enterprise," 58 the equivalent of a single employer for the purpose of making a bargaining unit determination: Analytically, the Checker rule appears analogous to the judicial doctrine of "piercing the corporate veil." wo Where a single business or economic unit has been artificially carved into a number of separate corporate entities, courts have traditionally disregarded the fiction of separate identity in order to allow recovery against the assets of the entire business. ${ }^{60}$ Similarly, in Checker the Board disregarded the separate identities of the composite companies in order to permit

\footnotetext{
52 Checker Cab Co., 141 N.L.R.B. 583 (1963), enforced, 367 F.2d 692 (6th Cir. 1966), appears to be the only case as yet to adopt the common control rule. It was distinguished in Cab Operating Corp., 1965 CCH NLRB 15974. See notes 55-60 infra and accompanying text.

${ }^{63}$ See notes 28-33 supra and accompanying text.

s. Western Ass'n of Engineers, 101 N.L.R.B. 64 (1952).

85141 N.L.R.B. 583 (1963), enforced, 367 F.2d 692 (6th Cir. 1966).

80 I41 N.L.R.B. at 584.

87 . at 587 .

68 Ibid.

${ }^{\circ 0}$ See generally LatTy \& Frampton, Basic Business Associations 711-20 (1963).

${ }^{\circ 0}$ E.g., Holland v. Joy Candy Mfg. Corp., 14 Ill. App. 2d 531, 145 N.E.2d 101 (1957); Chesapeake Stone Co. v. Holbrook, 168 Ky. 128, 181 S.W. 953 (1916); see Mull v. Colt Co., 31 F.R.D. 154 (S.D.N.Y. 1962).
} 
their empioyees the opportunity to bargain in a unit as broad as the actual employing entity.

At this point it is important to note that, although the Board has emphasized the consensual nature of its multiemployer unit criteria $^{61}$ and has on one occasion declared that "mutual consent of the union and employers involved is a basic ingredient necessary to support the appropriateness of a multiemployer unit," 62 the absence of such consent has not precluded a finding of appropriateness. ${ }^{63}$ Checker is an obvious example, ${ }^{64}$ but even in applying the Board's general bargaining history criterion, consent of the parties is not always necessary. ${ }^{65}$ In the typical case, where the employers and one union desire to bargain on a multiemployer basis and a second union desires single employer units, bargaining history is generally dispositive of the rival union's claim as to the scope of the appropriate unit. ${ }^{86}$ However, application of the bargaining history criterion is not confined to this narrow situation but is also available to settle disputes directly between the employers and the union as to the appropriateness of a multiemployer unit. ${ }^{67}$ Thus, although as a practical matter the parties must acquiesce in the initiation of group bargaining in order to develop a history of multiemployer bargaining; it is clear that the Board will not be foreclosed from finding a multiemployer unit appropriate if, at the time an official unit determination is to be made, one of the parties disagrees as to the scope of the unit, thereby destroying the mutuality of consent.

\footnotetext{
${ }^{61}$ See, e.g., Evening News Ass'n, 1965 CCH NLRB 16462, enforced sub nom. Detroit Newspaper Publishers Ass'n v. NLRB, 372 F.2d 569 (6th Cir. 1967); Andes Fruit Co., 124 N.L.R.B. 781 (1959).

${ }^{\circ}$ Id. at 783 .

ss See notes $26-29$ supra and accompanying text.

of 141 N.L.R.B. 583 (1963), enforced, 367 F.2d 692 (6th Cir. 1966). See notes 55-60 supra and accompanying text.

${ }^{\circ 6}$ Quality Limestone Prods., Inc., 143 N.L.R.B. 589 (1963); Stouffer Corp., 101 N.L.R.B. 1391 (1952); Johnson Optical Co., 85 N.L.R.B. 895, amended, 87 N.L.R.B. 539 (1949); Waterfront Employers Ass'n, 71 N.L.R.B. 80 (1946).

- See cases cited notes 47-50 supra and accompanying text.

o7 In Waterfront Employers Ass'n, 71 N.L.R.B. 80 (1946), for example, bargaining history was determinative in the absence of consent on the part of the employers involved; the Board held that it was "clear from the history of collective bargaining" that a multiemployer unit was appropriate. Id. at 112. The Board reached the same conclusion in Johnson Optical Co., 85 N.L.R.B. 895, 897, amended, 87 N.L.R.B. 539 (1949), "particularly in view of the past bargaining history" on a multiemployer basis. Similarly, when a union requested single employer units, the Board held a "10 year history of bargaining on a multiemployer basis ... enough to preclude a finding in derogation of that history." Stouffer Corp., 101 N.L.R.B. 1331, 1332 (1952).
} 


\section{WithdRAWAL FROM AN APPROPRIATE MULTIEMPLOYER}

\section{BARGAINING UNIT}

\section{A. Employer Withdrawal}

After the Board has found a multiemployer unit appropriate, it often develops that either an employer or the union desires to return to single employer bargaining. In Bercut-Richards Packing.Co., ${ }^{68}$ the first case to deal with the withdrawal issue, the Board granted to employers an unrestricted right of withdrawal from existing multiemployer bargaining units. It later reasoned that since its certification criteria required a manifestation of intent to be bound by group action in order to find a multiemployer unit appropriate, the "correlative" standard for withdrawal from such a unit was necessarily "evidence of an intent to pursue an individual course of action." However, because a refusal to bargain in the appropriate unit constitutes an unfair labor practice, ${ }^{70}$ the parties must know with reasonable certainty the scope of the appropriate bargaining unit. ${ }^{71}$ The Board soon realized, therefore, that despite the purported logic of permitting unrestricted employer withdrawal, ${ }^{22}$ such a policy would not provide the stability in bargaining relationships contemplated by the act. ${ }^{73}$

6s 68 N.L.R.B. 605 (1946).

${ }^{60}$ Pacific Metals Co., 91 N.L.R.B. 696, 699 (1950); accord, e.g., Economy Shade Co., 91 N.L.R.B. 1552,1553 n.4 (1950).

${ }^{70}$ Either a union under $\$ 8(\mathrm{~b})(3)$ (see note 96 infra) or an employer under $\$ 8(a)(5)$ (see note 110 infra) commits an unfair labor practice by failing to bargain in good faith in the appropriate unit. E.g., Hearst Consol. Publications, Inc., 1966 CCH NLRB 25213 (1965), enforced sub nom. Publishers' Ass'n v. NLRB, 364 F.2d 293 (2d Cir.), cert. denied, 385 U.S. 971 (1966) (employer); Evening News Ass'n, 1965 CCH NLRB 16462, enforced sub nom. Detroit Newspaper Publishers Ass'n v. NLRB, 372 F.2d 569 (6th Cir. 1967) (employer); Builders Institute, 142 N.L.R.B. 126 (1963) (union); Cascade Employers Ass'n, 127 N.L.R.B. 488 (1960) (union).

${ }^{71}$ See Meltzer, Single-Employer and Multi-Employer Lockouts Under the TaftHartley Act, 24 U. CHI. L. REv. 70, 96 (1956).

${ }^{72}$ Although purporting to be a matter of logic, the Board's "correlative" standard for withdrawal appears no more than a statement of policy. It does not necessarily follow that unilateral withdrawal must be permitted merely because an intent to be bound by group action was necessary initially to find a multiemployer unit appropriate. Moreover, the Board has not in all cases required that employers consent to bargain on a multiemployer basis before finding such a unit appropriate. See notes 26-29 supra and accompanying text.

${ }^{73}$ In the first case to impose restrictions on withdrawal from a multiemployer unit the Board reasoned that to permit an unlimited right of withdrawal "would not make for that stability in collective bargaining which the Act seeks to promote." Engineering Metal Prods. Co., 92 N.L.R.B. 823, 824 (1950). In a later case the Board justified its restrictions upon withdrawal as follows: "For the Board to tolerate 
Therefore, as early as 1950 the Board began to formulate rules to govern employer withdrawal which would ensure a reasonable degree of predictability as to the scope of the appropriate bargaining unit, particularly during negotiations. Without abandoning the theory that employers have a right to withdraw unilaterally from multiemployer units, limitations were imposed upon the time and manner in which that right could be effectively exercised. First, in Engineering Metals Prods. Corp.,$^{74}$ the Board held that withdrawal could .be made only at an "appropriate time." A year later in Washington Hardware Co., ${ }^{75}$ it refused to recognize a withdrawal because the employer had not manifested an "unequivocal intent" to abandon the multiemployer unit. ${ }^{76}$ Finally, in 1958 in Retail Associates, Inc. ${ }^{77}$ the Board in dictum clarified the meaning of "appropriate time". and "unequivocal intent" and imposed the additional requirement that an employer must give adequate written notice of its decision to withdraw. ${ }^{78}$

.. inconstancy and uncertainty in the scope of collective-bargaining units would be to neglect its function in delineating appropriate units . . . and to ignore the fundamental purpose. of the Act of fostering and maintaining stability in bargaining relationships. ... [T] he stability requirement of the Act dictates that reasonable controls limit the parties as to ... withdrawal ... from an established multiemployer unit." Retail Associates, Inc., 120 N.L.R.B. 388, 393 (1958).

7492 N.L.R.B. 823, 824 (1950).

7595 N.L.R.B. 1001, 1003 (1951).

10 Washington Hardware Co. appears to be the first case to deny withdrawal because the employers' intent was not unequivocal. Language suggesting that an unequivocal intent would be required initially appeared in Pacific Metals Co., 91 N.L.R.B. 696, 699 (1950). See note 69 supra and accompanying text. Later, in permitting employer withdrawal the Board stated that "if an employer at an appropriate time manifests an [un]equivocal intent to pursue an individual course in lis labor relations, a unit limited to his employees alone becomes appropriate." Milk \& Ice Cream Dealers, 94 N.L.R.B. 23, 25 (1951).

${ }^{77} 120$ N.L.R.B. 388, 395 (1958).

${ }^{78}$ The written notice requirement announced for the first time in Retail Associates apparently does not replace but merely supplements the Board's traditional requirement that withdrawal be unequivocal. This is evident from later decisions involving employer withdrawal which have turned on the equivocalness of the employer's intent to abandon group bargaining. E.g., Thomas H. Marrow Trucking Co., 1965 CCH NLRB 16607; Universal Insulation Corp., 149 N.L.R.B. 1397 (1964), enforced, 361 F.2d 406 (6th Cir. 1966); Anderson Lithograph Co., 124 N.L.R.B. 920 (1959), enforced sub nom. NLRB v. Jeffries Banknote Co., 281 F.2d 893 (9th Cir. 1960). In a subsequent case the Board stated: "The standards established for withdrawal from a multiemployer unit are ... that adequate written notice of an unequivocal intent to withdraw be given prior to the date established by the contract for modification." Evening News Ass'n, 1965 CCH NLRB 16470, 16471, enforced sub. nom. Detroit Newspaper Publishers Ass'n v. NLRB, 372 F.2d 569 (6th Cir. 1967). (Emphasis added.)

Aside from its importance in providing specific ground rules for employer withdrawal from multiemployer units, Retail Associates was also viewed as involving 
Thus, under the Board's present rules, to be effective employer wtihdrawal must be (1) timely, (2) unequivocal, and (3) in writing. ${ }^{79}$ The "appropriate time" for withdrawal is any time "prior to the date set by the contract for modification, or to the agreed-upon date to begin multiemployer negotiations." 80 Hence, once negotiations for a new multiemployer contract have begun, withdrawal will no longer be recognized by the Board and the employers must thereafter negotiate in good faith in the multiemployer unit. ${ }^{81}$ With respect to the second element, "unequivocal intent," as defined by the Board, means not only that an employer must express clearly its decision to withdraw, ${ }^{82}$ but also that such a decision "must contemplate a sincere abandonment, with relative permanency, of the multiemployer unit and the embracement of a different course of bargaining on an individual-employer basis." 83 An employer, therefore, who continues to participate in joint negotiations in derogation of its expressed desire to bargain individually has not unequivocally withdrawn from group bargaining. ${ }^{84}$ Moreover, "unequivocal in-

\footnotetext{
"a substantial departure from prior Board doctrine concerning the rights of unions .. . to withdraw from a multi-employer unit." 1959 A.B.A. LABOR RELATIONS SECTION 17. See generally notes 94-109 infra and accompanying text.

${ }^{70}$ E.g., Evening News Ass'n, supra note 78, at 16464; Quality Limestone Prods. Inc., 1965 CCH NLRB 16086; National Elec. Contractors' Ass'n, 181 N.L.R.B. 550, 552 n.3 (1961); see Halquist Lannon Stone Co., 1966 CCH NLRB 25305; Anderson Lithograph Co., supra note 78.

so Retail Associates, Inc., 120 N.L.R.B. 388, 395 (1958).

${ }^{81}$ E.g., Carmichael Floor Covering Co., 1965 CCH NLRB 16687; Quality Limestone Prods., Inc., 1965 CCH NLRB 16086; Spun-Jee Corp., 152 N.L.R.B. 943, 945 (1965); Kroger Co., 148 N.L.R.B. 569 (1964); Fairbanks Dairy, Inc., 146 N.L.R.B. 898, 897 (1964); Town \& Country Dairy, 136 N.L.R.B. 517 (I962). Moreover, an employer who fails to make a timely withdrawal but waits until a multiemployer contract has been negotiated before indicating an intent to abandon multiemployer bargaining violates the act by refusing to sign the group contract. E.g., Shamrock Systems, Inc., 1966 CCH NLRB 25119 (1965); Howard Disposal Corp., 1966 CCH NLRB 25130 (I965); Strong Roofing \& Insulating Co., 152 N.L.R.B. 9 (1965); McAnary \& Welter, Inc., 115 N.L.R.B. 1029, 1032 (1956).

82 The employers intent to abandon group bargaining must be unambiguously communicated to the union. See, e.g., Korner Kafe, Inc., 1966 CCH NLRB 254I5; Thomas H. Marrow Trucking Co., 1965 CCH NLRB 16607; Walker Elec. Co., I42 N.L.R.B. 1214, 1221 (1963). A withdrawal conditioned upon the employer's satisfaction with the terms of the group negotiated contract does not clearly evince a desire to discontinue multiemployer bargaining. E.g., Universal Insulation Corp., 149 N.L.R.B. 1897 (1964), enforced, 361 F.2d 406 (6th Cir. 1966); Carnation Co., 90 N.L.R.B. 1808 (1950).

${ }^{83}$ Retail Associates, Inc., 120 N.L.R.B. 388, 394 (1958).

${ }^{84}$ E.g., Oak Tree Farm Dairy, Inc., 1962 CCH NLRB 17607; Anderson Lithograph Co., 124 N.L.R.B. 920 (1959), enforced sub nom. NLRB v. Jefries Banknote Co., 281 F.2d 893 (9th Cir. 1960); see Walker Elec. Co., 142 N.L.R.B. 1214, 1221 (1963); Town \&
} 
tent" also includes the element of good faith, in the sense that withdrawal must not be frivolously employed merely "as a measure of momentary expedience, or strategy" 85 devoid of any serious desire or intention to bargain on a single employer basis. ${ }^{86}$ Finally, besides being timely and unequivocal, an effective withdrawal must be made in writing. ${ }^{87}$ This requirement appears to contemplate no more than a written communication to the union clearly expressing the employer's decision to withdraw from the existing multiemployer unit. 88

However, the foregoing rules governing the time and manner of employer withdrawal are subject to several qualifications. First, withdrawal from a certified multiemployer unit will not be permitted for a reasonable period of time, normally one year, after Board certification of the unit. ${ }^{80}$ Secondly, the Board's withdrawal rules

Country Dairy, 136 N.L.R.B. 517 (1962). Similarly, an employer who continues to adhere to the terms of a group negotiated contract cannot claim to have unequivocally withdrawn from multiemployer bargaining. See Thomas H. Marrow Trucking Co., 1965 CCH NLRB 16607.

${ }^{85}$ Retail Associates, Inc., 120 N.L.R.B. 388, 394 (1958).

80 In Retail Associates, Inc., supra note 85, at 394, the Board stated: "The element of good faith is a necessary requirement in any ... decision to withdraw, because of the unstabilizing and disrupting effect on multiemployer collective bargaining which would result if such withdrawal were permitted to be lightly made." Four years later, the Board, in holding a withdrawal ineffective, approved a Trial Examiner's finding that it "was more a tactical bargaining maneuver than a bona fide attempt to withdraw from multiemployer bargaining." Town \& Country Dairy, 136 N.L.R.B. 517, 523 (1962). A Trial Examiner in an opinion approved by the Board held that "even more important" than the untimeliness of an attempted withdrawal is "secrecy and want of good faith." Walker Elec. Co., 142 N.L.R.B. 1214, 1221 (1963). Moreover, in several cases the Board has refused to permit withdraval to be used as a tactical measure to affect the outcome of a representation election. Standard Register Co., 120 N.L.R.B. 1361 (1958); Blue Ribbon Prods. Co., 106 N.L.R.B. 562 (1953). See also Bell Bakeries, 139 N.L.R.B. 1344 (1962), explaining Dittler Bros., 132 N.L.R.B. 444 (1961). But see Bearing \& Rim Supply Co., 107 N.L.R.B. 101 (1953), where the Board stated that whatever reason an employer has for abandoning multiemployer bargaining is "immaterial."

${ }^{87}$ See note 78 supra and accompanying text.

${ }^{83}$ Although there appears to be no case as yet holding a withdrawal ineffective for lack of written notice, there is uo doubt that the Board has adopted this requirement. See Evening News Ass'n, 1965 CCH NLRB 16470, 16471. In a recent decision, for example, the Board held that "the requirement of written natice to effect a withdrawal from group bargaining presupposes the absence of consent to the withdrawal by other parties involved and is inapplicable to actions... which are taken by mutual consent." Halquist Lannon Stone Co., 1966 CCH NLRB 25305, 25307.

${ }^{80}$ E.g., Southwestern Colorado Contractors Ass'n, 1965 CCH NLRB 16056, 16057-58. The one-year rule stems from the principle approved by the Supreme Court that a bargaining unit certification (whether multiemployer or not) based on a Boardconducted election must be honored for a reasonable period of time. Brooks v. NLRB, 348 U.S. 96 (1954). 
are inapplicable ( 1 ) where the union consents expressly or impliedly to the employer's withdrawal, ${ }^{90}$ or (2) where in the Board's view "unusual circumstances" warrant an exception to its general rules. ${ }^{91}$ Under the union consent exception, compliance with the withdrawal rules is unnecessary where the union by tacit agreement ${ }^{92}$ or by actually bargaining with an employer on a single employer basis recognizes an otherwise ineffective withdrawal..$^{93}$ The exception for "unusual circumstances" is presently undefined, there having been no decisions allowing withdrawal on this ground.

\section{B. Union Withdrawal}

Although an employer's right to withdraw unilaterally from an appropriate multiemployer unit was established as early as $1946,{ }^{94}$ whether a union had the same right was not so readily determined. The earliest case to permit a union bargaining on a multiemployer basis to engage in single employer negotiations was Morand Bros. Beverage Co.95 In that case the Board held that a union violated neither section $8(\mathrm{~b})(3)^{96}$ nor section $8(\mathrm{~b})(\mathrm{l})(\mathrm{B})^{97}$ of the act by striking fewer than all the employer-members of a multiemployer unit after an impasse in group bargaining had been reached. ${ }^{98}$ Balancing the instability which would result from a complete collapse of negotiations against the benefits to be derived from continued bargaining with each employer individually, the Board

\footnotetext{
${ }^{\circ 0}$ Cases cited notes $92-93$ infra.

01 Retail Associates, Inc., 120 N.L.R.B. 388, 395 (1958) (dictum).

02 E.g., Indiana Limestone Co., 136 N.L.R.B. 697 (1962).

${ }^{03}$ E.g., Atlas Sheet Metal Works, Inc., 148 N.L.R.B. 27 (1964); C \& M Constr. Co., 147 N.L.R.B. 843 (1964); Metke Ford Motors, Inc., 137 N.L.R.B. 950 (1962).

os See note 68 supra and accompanying text.

os 91 N.L.R.B. 409 (1950), enforcement denied on other grounds, 190 F.2d 576 (7th Cir. 1951), on remand, 99 N.L.R.B. 1448 (1952), enforced, 204 F.2d 529 (7th Cir. 1953).

${ }^{\circ}$ Section 8 (b) (3) provides that “ (b) It shall be an unfair labor practice for a labor organization or its agents- ... (3) to refuse to bargain collectively with an employer, provided it is the representative of his employees ..." 61 Stat. 140 (1947), 29 U.S.C. $\S 158$ (b) (3) (1964).

${ }^{87}$ Section 8 (b) (1) (B) provides that “ (b) It shall be an unfair labor practice for a labor organization or its agents-(1) to restrain or coerce ... (B) an employer in the selection of his representatives for the purposes of collective bargaining or the adjustment of grievances . . ." 61 Stat. 141 (1947), 29 U.S.C. $\$ 158$ (b) (1) (B) (1964).

${ }^{98}$ Although the Board in Morand Bros. did not frame its discussion in terms of withdrawal, nevertheless, by permitting the union to strike fewer than all the employermembers of a multiemployer unit and then to negotiate with them individually, the Board in effect allowed the union to withdraw from the multiemployer unit. See Note, 66 HARv. L. REv. 886, 894 (1953).
} 
reasoned that the purpose of the act would best be served by permitting unions to bargain on a single employer basis "where negotiations on a multiemployer basis have broken down." Bo By legalizing "whipsaw" strikes against the employer-members of a multiemployer unit, Morand Bros. undoubtedly provided the stimulus for the development several years later of a correlative right on the part of employers to lockout in order to defend against such tactics. ${ }^{100}$ However, the most significant aspect of Morand Bros. in regard to union withdrawal was the Board's view of the congressional intent underlying section 8 (b) (1) (B) of the act. Faced with the argument that Congress enacted this section to prevent unions from coercing "an employer into joining or resigning from an employer association," 101 the Board reasoned that to permit union withdrawal under the circumstances would not conflict with that purpose, since it "was not inconsistent with retention by the [employers] . . . of their membership" in the representative association. ${ }^{102}$

During the eight years between Morand Bros. and the next decision on the question of union withdrawal, it was generally assumed that the Board intended that unions should not have the same rights of withdrawal from multiemployer units as employers. ${ }^{103}$ 1t came as somewhat of a surprise, therefore, when in 1958 in Retail Associates, Inc. ${ }^{104}$ the Board announced that in future cases, where the issue of withdrawal was squarely presented, either "an employer or a union" could effectively withdraw from an appropriate multi-

9091 N.L.R.B. at 418.

100 See notes 145-66 infra and accompanying text.

10191 N.L.R.B. at 425 (dissenting opinion).

${ }^{103} I d$. at 416 . In subsequent cases the Board has held that whether a union violates $\$ 8(\mathrm{~b})(\mathrm{l})(\mathrm{B})$ (see note 97 supra) by seeking separate negotiations or striking fewer than all of the employer-members of a multiemployer unit depends upon its motivation, that is, where it is attempting to force the employers to forego bargaining through their selected representative or merely trying to reach a contract settlement. Compare Cascade Employers' Ass'n, 141 N.L.R.B. 469 (1963), where the Board held that union attempts to coerce withdrawals of employers from an employer association violated 8 (b)(l)(B), with Cheney California Lumber Co., 130 N.L.R.B. 235, 242 (1961), aff'd, 319 F.2d 375 (9th Cir. 1963), where the Board held that a union did not restrain or coerce an employer in the selection of its bargaining representative, since the strike in question was not called because of any objection to dealing with the employer association, but rather because of a disagreement over contract terms. ${ }^{208}$ Cf., e.g., Local 449, Teamsters Union v. NLRB, 231 F.2d 110 (2d Cir. 1956) (dictum), rev'd on other grounds, 353 U.S. 87 (1957); Continental Baking Co., 99 N.L.R.B. 777, 778 (1952) (dissenting opinion); Jones, The NLRB and the Multiemployer Unit, 5 LAB. L.J. 34, 38-39 (1954); Note, 66 HARv. L. REv. 886, 894-95 (1953). 104120 N.L.R.B. 388 (1958). 
employer unit by giving adequate written notice of its unequivocal intent to abandon group bargaining prior to the commencement of negotiations for a new multiemployer contract. ${ }^{105}$ Although dictum, the ground rules for withdrawal enunciated in Retail Associates quickly became necessary requirements for effective employer withdrawal. ${ }^{108}$ Yet, it was not until 1965 in Evening News Ass' $n^{107}$ that the Board opened wide the "door left slightly ajar"108 in Retail Associates by specifically holding that "the existing rules governing employer withdrawal from multiemployer units should be applied on an equal basis to union withdrawal from such units."109

${ }^{108}$ In Retail Associates the employers had filed a petition for an election in the existing multiemployer unit to test the majority status of the incumbent union, but the union, to avoid the election, disclaimed representation of the employees involved on a multiemployer basis. The Board, nevertheless, directed an election in the multiemployer unit. However, before the Board was able to issue a formal opinion, the union petitioned a federal district court to enjoin the Board from following a "discriminatory rule." The court granted a preliminary injunction, holding that because it was the Board's established policy to permit employers to withdraw from multiemployer units virtually at will (see notes 68-93 supra and accompanying text), denial of the same right to unions "would appear to be arbitrary in exccss of the Board's statutory authority, and to deprive [unions] . . . and the employees they represent of due process of law . ..." Retail Clerks Local 128 y. Leedom, 34 CCH Lab. Cas. 96624 (D.D.C., April 29, 1958).

When the Board finally issued its opinion in Retail Associates, it made no reference to the injunction and supported its decision on the ground that the union had not effectively disclaimed representation. However, the Board then proceeded in dictum to grant prospectively to unions the same rights as employers to withdraw from existing multiemployer units. The Board stated that "the Union argues strongly that under the Board's rules it may never be given the opportunity to withdraw from a multiemployer bargaining unit although such a right is accorded employers. While . . . this extreme question does not arise in this case, we believe it reasonable to establish in appropriate future cases, where such issues are squarely presented, specific ground rules ... to govern questions of representation in multiemployer bargaining units. ... We would accordingly refuse to permit withdrawal of an employer or a union from a duly established multiemployer unit, except [upon written notice prior to negotiations] ..." 120 N.L.R.B. at 394-95. (Former emphasis in original; latter emphasis added.)

${ }^{100}$ See, e.g., Quality Limestone Prods., Inc., 1965 CCH NLRB 16086; Sheridan Creations, Inc., 148 N.L.R.B. 1503 (1964), enforced, 357 F.2d -245 (2d Cir. 1966); National Elec. Contractors' Ass'n, 131 N.L.R.B. 550, 552 n.3 (1961); Anderson Lithograph Co., 124 N.L.R.B. 920 (1959), enforced sub nom. NLRB v. Jefferies Banknote Co., 281 F.2d 893 (9th Cir. 1960).

1071965 CCH NLRB 16462, enforced sub. nom. Detroit Newspaper Publishers Ass'n v. NLRB, 372 F.2d 569 (6th Cir. 1967), 41 N.Y.U.L. REv. 651 (1966), 44 TeXAs L. REv. 1047 (1966).

1081966 A.B.A. Labor Relations Section 423.

${ }^{100} 1965$ CCH NLRB at 16467. Since Evening News, the Board has permitted union withdrawal in two other cases. Adams Furnace Co., 1966 CCH NLRB 26871; Hearst Consol. Publications, Inc., 1966 CCH NLRB 25213 (1965), enforced sub nom. Publishers Ass'n v. NLRB, 364 F.2d 293 (2d Cir.), cert. denied, 385 U.S. 971 (1966). 


\section{The Evening News Case}

In Evening News several Detroit newspapers had bargained with the union on a multiemployer basis for a period of twenty-five years. About two months before the expiration of the then current collective bargaining agreement, the union, apparently relying on the withdrawal rules announced prospectively in Retail Associates, served written notice of its desire to negotiate future contracts on a single employer basis. The newspapers, however, refused the union's request for individual bargaining and a complaint was filed against them alleging an unlawful refusal to bargain in the appropriate unit in violation of section $8(a)(5)^{110}$ of the act. The Board agreed with the Trial Examiner that the newspapers had indeed committed an unfair labor practice by refusing to bargain with the union on a single employer basis, since it was determined that the union had effectively withdrawn from the existing multiemployer unit.111

After citing two judicial opinions which intimated that it would be arbitrary and an abuse of discretion for the Board to adopt more restrictive standards to govern union withdrawal than those applicable to employers, ${ }^{112}$ the Board reasoned that

the basis of a multiemployer bargaining unit [being] . . . both original and continuing consent by both parties, [it follows that] the Board cannot logically deny [the union] ... the same opportunity it allows employers of withdrawing from the multiemployer unit by withdrawing its consent to such unit. ${ }^{113}$

Moreover, the Board could find no justification for treating employer and union withdrawal differently. ${ }^{114}$ The employers had contended that more restrictive rules should govern union with-

\footnotetext{
${ }^{110}$ Section 8 (a) (5) provides that " (a) It shall be an unfair lahor practice for an employer- ...(5) to refuse to bargain collectively with the representatives of his employees ...." 61 Stat. 141 (1947), 29 U.S.C. § 158 (a) (5) (1964).

$1111965 \mathrm{CCH}$ NLRB at 16463.

${ }^{112}$ Local 449, Teamsters Union v. NLRB, 231 F.2d 110 (2d Cir. 1956) (dictum), rev'd on other grounds, 353 U.S. 87 (1957) and Retail Clerks Local 128 v. Leedom, 34 CCH Lab. Cas. 96624 (D.D.C., April 29, 1958), cited in Evening News, $1965 \mathrm{CCH}$ NLRB at 16464 .

${ }^{113}$ Id. at 16464. Member Brown, dissenting, disagreed that the continuing consent of both parties is alone the basis for a multiemployer unit. He argued that multiemployer bargaining history is a material factor in determining the appropriate unit and that the statutory objective of promoting stable collective bargaining relationships would not he served by permitting a union to withdraw at will from an existing multiemployer unit without showing a legitimate reason for doing so. Id. at 16467-68.

$114 I d$. at 16466 .
} 
drawal on the ground that when a union withdraws from a multiemployer unit it enhances its bargaining strength vis-à-vis the employers. ${ }^{115}$ More specifically, the employers were concerned that union withdrawal would preclude them from utilizing a multiemployer lockout to defend against "whipsaw" strikes. ${ }^{116}$ The Board, however, rejected this argument on the ground that "the Act nowhere says that, in determining the appropriateness of a unit, the Board shall consider the relative bargaining power of the parties."117 In addition, it felt that the practical consequence of not according unions the same right to withdraw that employers have would either (1) discourage unions from bargaining on a multiemployer basis, or (2) encourage unions already bargaining on such a basis to stimulate employer withdrawals by insisting on demands unacceptable to some employers. ${ }^{118}$ Thus, "inequality of freedom to withdraw . . could become a means of producing, not stability, but friction and instability in the bargaining unit." 110

Because the Evening News decision has caused alarm in some quarters and may have an adverse effect upon the future of multiemployer bargaining, ${ }^{120}$ its soundness warrants careful examination. The majority chose to rely on two basic arguments: (1) under the Board's established criteria for finding a multiemployer unit appropriate, it cannot "logically" deny either the employers or the union the right to withdraw at will; ${ }^{121}$ (2) for the Board to adopt different,

$115 \mathrm{Id}$. at 16464-65. The employers argued that when a union withdraws, it still continues to represent all the employees that made up the former multiemployer unit, while the employers are forced to bargain with the union individually. Hence, because the union can maintain its organizational strength and at the same time preclude the employers from bargaining with it as a group, the bargaining power of the former employer-members of the multiemployer unit is significantly weakened. See note 4 supra and accompanying text.

${ }_{110} 1965 \mathrm{CCH}$ NLRB at 16465. The employers' contention that union withdrawal would preclude them from using the multiemployer lockout is another aspect of their bargaining power argument. If employers could not combat "whipsaw" strikes with a group lockout, their bargaining power would, of course, be greatly decreased. See note 5 supra and accompanying text. The Board left open for future consideration the question whether union withdrawal from an existing multiemployer unit would make it unlawful for the former employer-members to lockout as a defense against union "whipsawing." 1965 CCH NLRB at 16465. See generally notes 145.66 infra and accompanying text.

$1171965 \mathrm{CCH}$ NLRB at 16465.

118 Id. at 16466 .

$110 I d$. at 16466 .

${ }^{120}$ See, e.g., Detroit Newspaper Publishers Ass'n v. NLRB, 372 F.2d 569, 572 (6th Cir. 1967).

${ }^{121}$ See note 113 supra and accompanying text. 
more restrictive rules for union withdrawal would be arbitrary and an abuse of discretion in excess of its statutory authority. ${ }^{122}$

Stated in its simplest terms, the Board's first argument is that the appropriateness of a multiemployer unit depends upon the mutual consent of the parties, both at the time of its creation and throughout the period of its existence. Thus, it logically follows that both unions and employers are entitled to withdraw by terminating their consent. If one accepts the majority's major premise, its conclusion is, of course, inescapable. The question, however, remains: Is the mutual consent premise valid in light of the Board's established criteria for finding and continuing to recognize the appropriateness of a multiemployer bargaining unit t23 $^{23}$ According to the majority, the very existence of an appropriate multiemployer unit has always depended upon mutual consent, because

the Board does not find [such a unit] . . . appropriate except where all the parties clearly agree ... or where there has been a history of bargaining on a multiemployer basis and the employers and either the incumbent or rival union desire to continue bargaining on such a basis. ${ }^{124}$

Such a statement, however, inaccurately summarizes the application of the Board's established multiemployer unit criteria. It obviously iguores the Checker $\mathrm{Ca} b^{125}$ decision in which neither lack of mutual consent nor absence of bargaining history prevented the Board from finding a multiemployer unit appropriate. Furthermore, even if Checker $C a b$ were viewed as an aberrational case, the majority erroneously portrayed the Board's bargaining history criterion as decisive only in those cases where "the employers and either the incumbent or rival union desire to continue bargaining on [a multi-

\footnotetext{
122 Although not expressly stated as such, the abuse of discretion argument is implicit in the majority opinion. The majority defined the issue presented to be "whether the Board can or should adopt different, more restrictive, rules to govern a union's withdrawal from multiemployer units than now exist to govern employer withdrawals." $1965 \mathrm{CCH}$ NLRB at 16464. It then proceeded to quote from opinions of two reviewing courts indicating that it would be an abuse of discretion for tbe Board to adopt more restrictive standards for union than employer withdrawal. Cases cited note 112 supra. Finally, the majority devoted much of its opinion to refuting the employers' contention that union withdrawal differed from employer withdrawal to such an extent that the Board could reasonably adopt more stringent standards to govern that situation. See $1965 \mathrm{CCH}$ NLRB at 16464-65.

128 See notes $34-93$ supra and accompanying text.

1241965 CCH NLRB at 16464.

${ }^{125} 141$ N.L.R.B. 583 (1963), enforced, 367 F.2d 692 (6th Cir. 1966). See notes 55-60 supra and accompanying text.
} 
employer] . . . basis." 126 If this were true, bargaining history would be irrelevant where there was a dispute between the employers and a single union, and the employers or the union by withholding consent could in fact determine the appropriate unit. Recognizing this possibility, the Board has in several cases relied upon bargaining history to support the appropriateness of a multiemployer unit despite the opposition of either an employer or a union. ${ }^{227}$ Thus, contrary to the majority's assertion, an appropriate multiemployer unit has not always been "rooted in consent" of the parties.

Even more difficult to support is the proposition advanced by the majority that the continued existence of an established multiemployer unit has always depended upon the "continuing consent" of the parties. ${ }^{128}$ The Board itself has said that "the right of withdrawal . . f from a multiemployer unit has never been held ... to be free and uninhibited, or exercisable at will or whim."128 As the dissenting member indicated, ${ }^{130}$ the right to withdraw has been limited to the extent that it must be timely, unequivocal, and in writing; ${ }^{131}$ and in the absence of meeting these three requirements employers have traditionally been included in multiemployer units despite their protests. ${ }^{132}$ Of course, in any case in which withdrawal is permitted there will necessarily be a coincident failure of consent, but those cases in which the Board has held an attempted withdrawal ineffective ${ }^{133}$ negate the conclusion that mutual consent alone is determinative of the continued appropriateness of a multiemployer unit.

The second argument implicit in the majority opinion appears more tenable, for two courts have stated that the adoption by the Board of more restrictive standards to govern union withdrawal than those applicable to employers would be an abuse of its administrative discretion. ${ }^{134}$ The employers in Evening News had contended that the Board could rationally adopt more restrictive rules for union withdrawal, because when a union withdraws, its bargain-

\footnotetext{
1201965 CCH NLRB at 16464.

${ }^{12 \pi}$ Cases cited note 65 supra. See notes 25-29 supra and accompanying text.

${ }^{228} 1965 \mathrm{CCH}$ NLRB at 16464.

229 Retail Associates, Inc., 120 N.L.R.B. 388,393 (1958).

$1801965 \mathrm{CCH}$ NLRB at 16468.

${ }^{132}$ See notes 74-93 supra and accompanying text.

232 E.g., cases cited notes 81, 84-86 supra.

$28 s$ Ibid.

194 Cases cited note 112 supra.
} 
ing power is enhanced, especially if by doing so it can preclude the utilization by employers of a multiemployer lockout; whereas when employers withdraw, their bargaining power is decreased. ${ }^{135}$ In light of recent admonitions from the Supreme Court that the Board is not "to act at large in equalizing disparities of bargaining power"180 nor "to deny weapons to one party or the other because of its assessment of that party's bargaining power,"137 it seems that the majority properly concluded that the possible effect of union withdrawal on the relative economic strength of the parties could not alone justify the Board's adoption of a double withdrawal standard.138 Moreover, under its established criteria for finding multiemployer units appropriate, the Board has never given consideration to the effect that its unit determination would have on the bargaining power available to the parties. ${ }^{130}$

However, even if one accepts the proposition that it would be an abuse of discretion-in the absence of authority under the act to consider relative bargaining power-for the Board to restrict union withdrawal while permitting employers to withdraw at will, ${ }^{140}$ the

\footnotetext{
${ }^{185}$ See notes 115-16 supra and accompanying text.

${ }^{180}$ NLRB v. Insurance Agents Union, 361 U.S. 477, 490 (1960).

182 American Ship Bldg. Co. v. NLRB, 380 U.S. 300, 317 (1965).

${ }^{238}$ In view of the declarations by the Supreme Court that the Board is not to be an arbiter of the bargaining power available to the parties, it is not surprising that the Second Circuit in a case factually similar to Evening News upheld the Board's union withdrawal position on review, stating that to require "the Board to weigh and act on ... relative bergaining strength ... in determining the appropriateness of bargaining units, would seem enough of a departure from the general scheme of the Act to call for explicit statutory provisions." Publishers' Ass'n v. NLRB, 364 F.2d 293, 296 (2d Cir.), cert. denied, 385 U.S. 971 (1966).

Relative bargaining power has been criticized as a tool for legal analysis, since when invoked it is merely a claim by one party that it "should have an increase in hargaining poiver relative to another," a claim which may have little relation to the merits of the dispute. See Meltzer, Single-Employer and Multi-Employer Lockouts Under the TaftHartley Act, 24 U. CHI. L. REv. 70, 83 (1956). Moreover, economists have long criticized the "bargaining power" concept because it "is dependent at least as much upon what each party is seeking . . . as it is upon each party's coercive ability." CHaMBERLAin, Collective Bargaining 236 (1951). See generally Stigler, The Economist Plays IVith Blocs, 44 Am. Econ. Rev. (PAPERs \& Proceedings) 7, 14 (1954).

${ }^{139} 1965 \mathrm{CCH}$ NLRB at 16465. See notes 36.60 supra and accompanying text.

${ }^{160}$ The Board appears correct in its view that, absent the authority to consider the relative bargaining power of the parties, it would he irrational and arbitrary to deny unions the same right as employers to withdraw from existing multiemployer units. Under existing Board rules employers can effectively destroy an appropriate multiemployer unit by withdrawing en masse. See, e.g., Swanson Logging Co., 111 N.L.R.B. 495 (1955); Johnson Optical Co., 87 N.L.R.B. 539 (1949). In the case of either employer or union withdrawal, therefore, the existing multiemployer unit can be destroyed unilaterally and the withdrawing party forces the other to forego bargaining on a group basis.
} 
Board is, nonetheless, open to criticism for failing to consider the obvious alternative to an arbitrary double standard-namely, equal but stringent restrictions upon both union and employer withdrawal. ${ }^{141}$ In failing to consider this alternative the Board appears to have become excessively concerned with the consequences of "inequality of freedom to withdraw"142 and never to have confronted the real issue: Whether "the fundamental purpose of the Act to foster and maintain stability in bargaining relations" ${ }^{\prime 143}$ is served by permitting parties bargaining in an appropriate multiemployer unit to alter or destroy that unit at will..$^{144}$

Even assuming, however, that the Board could, without abusing its discretion, adopt more restrictive rules to govern union than employer withdrawal, its decision in Evening News was certainly within its wide administrative discretion. See note 35 supra and accompanying text. Indeed, the Sixth Circuit's decision enforcing the Board's order in Evening News noted that union withdrawal regulation "is an area which Congress has confided to the discretion and expertise of the Board, and in which the Courts may not interfere unless the Board violates the statute or abuses its discretion." Detroit Newspaper Publishers Ass'n v. NLRB, 372 F.2d 569, 571 (6th Cir. 1967).

141 More restrictive withdrawal standards for both employers and unions would be consistent with the Board's concern for equality of treatment, since the standards would apply equally to either party. Moreover, "underlying the entire statutory scheme which has been interpreted to authorize [multiemployer units] ... is the notion that they serve the important public interest ... as well as the interest of the immediate parties." Id. at 572; see 44 Texas L. REv. 1047 (1966).

The fact that the narrow question of employer withdrawal was not directly before the Board in Evening News provides little excuse for the Board's failure to consider the adoption of more restrictive withdrawal standards for both parties. Unless the Board adopts withdrawal rules applicable to both unions and employers in a case involving withdrawal by only one party, it may be precluded by its equality of treatment rationale from promulgating more restrictive withdrawal rules in future cases, since no single case will involve both employer and union withdrawal. Under existing Board rules where both parties agree withdrawal is permitted despite the restrictions that would otherwise apply. See notes 90, 92-93 supra and accompanying text.

12 See notes 118-19 supra and accompanying text. As the court in enforcing Evening News indicated, "an analysis of the situation reveals that equality of withdrawal rights is only half of the issue at stake. Besides insuring equal treatment of unions and employers, . . B Board policies should be framed substantively to bolster the multiemployer unit as an instrument of national policy." Detroit Newspaper Publishers Ass'n v. NLRB, 372 F.2d 569, 572 (6th Cir. 1967).

${ }^{143}$ Retail Associates, Inc., 120 N.L.R.B. 388, 393 (1958).

34 "Under the Act, multiemployer bargaining units can be accorded the sanction of the Board only insofar as they rest in principle on a relatively stable foundation." Retail Associates, Inc., 120 N.L.R.B. 388, 393 (1958). Thus, the Board's primary consideration in finding and continuing to recognize the appropriateness of such units must necessarily be the stability in bargaining relations that multiemployer bargaining under the circumstances would tend to promote or maintain. This is not to deny the significance of mutual consent, for in many cases the fact that the parties agree to bargain on a multiemployer basis is probably indicative of a stable bargaining relationslip. See note 33 supra and accompanying text. However, there may be situations where giving determinative weight to consent alone would confiict rather than coincide 


\section{The Consequences of Permitting Unilateral Withdrawal From MULTIEMPloyer Bargaining Untts}

\section{A. The Effect of Union Withdrawal on the Right of Employers to Lockout}

In 1954 the Board took the position later upheld by the Supreme Court in NLRB v. Local 449, Teamsters Union (Buffalo Linen) ${ }^{145}$ that

a strike against one employer-member of a multiemployer bargaining unit constitutes a threat of strike action against the other employers, which threat, per se . . . legally justifies their resort to a temporary lockout of employees. ${ }^{446}$

with the stability in bargaining contemplted by the act. See, e.g., cases cited notes $65,81,84,86$ supra. When this is the case the fundamental purpose of the act requires that the stability of collective bargaining be given priority. Ibid.

${ }_{165} 353$ U.S. 87 (1957), reversing 231 F.2d 110 (2d Cir. 1956), denying enforcement sub nom. Buffalo Linen Supply Co., 109 N.L.R.B. 447 (1954), 57 CoLvM. L. Rev. 1172 (1957), 42 VA. L. REv. 684 (1956).

160 109 N.L.R.B. at 448. Prior to Buffalo Linen the Board had held that the use of a lockout by the nonstruck employer-members of a multiemployer unit to counter union "whipsawing" and not as a necessary device to avoid direct economic loss was an unfair labor practice in the form of an unlawful reprisal against the employees' protected right to strike. E.g., Davis Furniture Co., 94 N.L.R.B. 279 (1951), enforcement denied sub nom. Leonard v. NLRB, 197 F.2d 435 (9th Cir. 1952), on remand, 100 N.L.R.B. 1016 (1952), enforcement denied sub nom. Leonard v. NLRB, 205 F.2d 355 (9th Cir. 1953); Morand Bros. Beverage Co., 91 N.L.R.B. 409 (1950), enforcement denied, 190 F.2d 576 (7th Cir. 1951), on remand, 99 N.L.R.B. 1448 (1952) (dictum), enforced on other grounds, 204 F.2d 529 (7th Cir. 1953).

Apparently at common law an employer had the right to lockout, or even discharge, his employees for any reason, so that for all practical purposes the lockout was the corollary of the right to strike. See, e.g., Iron Moulders' Union v. Allis-Chalmers Co., 166 Fed. 45, 50 (7th Cir. 1908) (dictum). Neither the original National Labor Relations Act (49 Stat. 449 (1935)), nor the Taft-Hartley Amendments (61 Stat. 136 (1947), 29 U.S.C. $\$ \$ 141-97$ (1964)) expressly prohibit the lockout. See NLRB v. Local 449, Teamsters Union, 353 U.S. 87, 92 (1957). A lockout is only unlawful, therefore, if it is an unlawful interference, coercion, or restraint of protected employee activity under $\$ 8$ (a) (1) of the act. See NLRB v. Somerset Shoe Co., 111 F.2d 681, 689 (lst Cir. 1940). Conversely, the lockout is entirely lawful "provided only that the employer's action is not motivated by a purpose to interfere with and defeat its employees' union activities." Pepsi Cola Bottling Co., 72 N.L.R.B. 601, 602 (1946); accord, e.g., Bisbee Linseed Co., 18 N.L.R.B. 993 (1939). Thus, the Board has held that a lockout is lawful when motivated by a desire to avoid peculiar economic loss incident to a strike, such as spoilage of materials, or the threat of recurrent work stoppages which make continued operations uneconomical. E.g., Betts Cadillac Olds, Inc., 96 N.L.R.B. 268 (1951); International Shoe Co., 93 N.L.R.B. 907 (1951); Duluth Bottling Ass'n, 48 N.L.R.B. 1335 (1943). Prior to Buffalo Linen, however, the Board made it clear that the use of the lockout solely for the purpose of defending against a "whipsaw" strike was unlawful. E.g., Continental Baking Co., 104 N.L.R.B. 143, 146 (1953) (dictum), enforcement denied on other grounds, 221 F.2d 427 (8th Cir. 1955); Davis Furniture Co., supra; Morand Bros. Beverage Co., supra. 
By permitting the nonstruck employer-members of a multiemployer unit to lockout, Buffalo Linen combined with later cases provided employers with a potent defense against union "whipsaw" strike tactics. ${ }^{14 \pi}$ However, the Board narrowly construed Buffalo Linen as making the defensive lockout available only to those employers who are actually members of an appropriate multiemployer unit. In Evening News Ass' $n,^{148}$ for example, it held that a lockout by one newspaper when another was struck violated sections $8(a)(1)$ and (3) of the act because the two newspapers were not members of an appropriate multiemployer unit. The Board reasoned that the Buffalo Linen lockout is permitted only to preserve an existing multiemployer unit from threatened destruction and was not therefore available when such a unit did not exist. ${ }^{140}$ Shortly after the Board's decision in Evening News, the Supreme Court in American Ship Bldg. Co. v. $N L R B^{150}$ held that a single employer does not violate the act when, after an impasse in negotiations, he temporarily locks out his employees "for the sole purpose of bringing economic pressure to bear in support of his legitimate bargaining position."151 The Court reasoned that a lockout as such is not the sort of employer

${ }^{147}$ After Buffalo Linen the Board continued to recognize the lockout as a legitimate defensive measure available to the employer-members of a multiemployer unit. See, e.g., Natkin \& Co., 150 N.L.R.B. 1542 (1965); Publishers' Ass'n, 139 N.L.R.B. 1092 (1962), enforced sub nom. New York Mailers' Union No. 6 v. NLRB, 327 F.2d 292 (2d Cir. 1964). The Board in post-Buffalo Linen cases held, however, that the temporary replacement of locked out employees and the continued operation of business was unlawful. E.g., Missoula Motel Ass'n, 148 N.L.R.B. 1477 (1964); Bagdad Bowling Alleys, 147 N.L.R.B. 851 (1964); Kroger Co., 145 N.L.R.B. 235 (1963). The Board reasoned that as long as the non-struck employers did not replace their locked out employees, they were still arguably defending themselves or the integrity of the multiemployer unit against "whipsaw" tactics, but that in hiring replacements their conduct hecame retaliatory and punished their regnlar employees for being members of the striking union. The Supreme Court, however, rejected the Board's reasoning and concluded that absent specific antiunion motivation the hiring of temporary replacements and the continued operation of the employer's business was not a violation of the act. NLRB -v. Brown, 380 U.S. 278 (1965), affirming 319 F.2d 7 (10th Cir. 1963), denying enforcement of 137 N.L.R.B. 79 (1962), 17 SYRAcuse L. REv. 66 (1966), 18 U. FLA. L. REv. 457 (1966).

${ }_{148} 145$ N.L.R.B. 996 (1964), enforcement denied sub nom. Detroit Newspaper Publishers Ass'n v. NLRB, 346 F.2d 527 (6th Cir. 1965), vacated per curiam sub nom. Newspaper Drivers \& Handlers Local 372 v. Detroit Newspaper Publishers Ass'n, 382 U.S. 374 (1966). This is an earlier case involving the same employers as in the principal union withdrawal decision under discussion in this comment.

160145 N.L.R.B. at 1001 .

180380 U.S. 300 (1965), reversing 331 F.2d 839 (D.C. Cir. 1964), enforcing 142 N.L.R.B. 1362 (1963), 1966 DUkE L.J. 261, 64 MICH. L. REv. 910 (1966), 17 SYrAcuSE L. Rev. 66 (1965), 18 VAND. L. Rev. 2056 (1965). 151380 U.S. at 318 . 
action which is so destructive of collective bargaining that the Board need not inquire into the employer's motivation. ${ }^{152}$ Therefore, the Court concluded, "proper analysis of the problem demands that the simple intention to support the employer's bargaining position . . . be distinguished from a hostility to the process of collective bargaining."153 On review of the Evening News decision the Sixth Circuit in Detroit Newspaper Publishers Ass'n v. NLRB,154 reading American Ship Bldg. to require a demonstration of "antiunion animus" before a lockout becomes unlawful, denied enforcement of the Board's order. The court held that absent evidence of hostile motivation employers bargaining together with the same union could lawfully lockout to defend against a "whipsaw" strike even if they are not members of an existing multiemployer unit; for in the court's opinion such action furthers a legitimate bargaining interest. ${ }^{155}$ The status of Detroit Newspaper Publishers, however, remains uncertain, since the Supreme Court vacated the decision of the court of appeals and remanded the case to the Board for reconsideration in light of American Ship Bldg. ${ }^{156}$

Between the time the Sixth Circuit reversed the Board in Detroit Newspaper Publishers and the Supreme Court's decision to remand that case, the Board decided in Weyerhauser Co. ${ }^{157}$ that even if nonstruck employers are mistaken as a matter of law with respect to their membership in an appropriate multiemployer unit, a lockout by them in support of a struck employer is not unlawful. The Board held that the principles announced by the Supreme Court in American Ship Bldg. ${ }^{158}$ and its companion case, NLRB v. Brown, ${ }^{159}$ apply to the situation where two or more employers bargain jointly with the same union and the union strikes only some of the employers, because "the subsequent lockout by the nonstruck employers in that

\footnotetext{
152 Id. at 309 .

153 Ibid.

154 346 F.2d 527 (6th Cir. 1965), 15 CATHOLIC U.L. REv. 136 (1966).

${ }^{155}$ See 346 F.2d at 531-32.

${ }^{150}$ Newspaper Drivers \& Handlers Local 372 v. Detroit Newspaper Publishers Ass'n, 382 U.S. 374 (1966) (per curiam).

${ }^{157} 1966$ CCH NLRB 25093, remanded sub nom. Western States Regional Council v. NLRB, 365 F.2d 934 (D.C. Cir. 1966).

${ }^{158}$ See notes $150-53$ supra and accompanying text.

${ }^{150} 380$ U.S. 278 (1965), affirming 319 F.2d 7 (10th Cir. 1963), denying enforcement of 137 N.L.R.B. 73 (1962), 17 Syracuse L. Rev. 66 (1966), 18 U. FlA. L. REv. 457 (1966). See note 147 supra.
} 
situation clearly lacks the discriminatory motivation required by the Court's holdings while it does serve a 'significant employer interest ...." "160 The Weyerhauser rationale would seem to be equally applicable to employers who were members of an appropriate multiemployer unit before union withdrawal. However, Weyerhauser was remanded to the Board on review by the District of Columbia Circuit. ${ }^{161}$

Thus, the question whether the employer's right to lockout to defend against a "whipsaw" strike will survive withdrawal by the union from an existing multiemployer unit still remains to be decided by the Board. The practical consequence of the Board's decision to permit unilateral union withdrawal from existing multiemployer bargaining units will, of course, be greatly affected by that decision. Not only would the value of multiemployer bargaining to employers be significantly diminished without the right to lockout, but unions would be provided with an enticing incentive to withdraw whenever it appeared that in upcoming negotiations their demands would not be met without resort to economic force. American Ship Bldg. and Brown would seem to provide the Board with ample precedent to find that former members of a multiemployer unit have a sufficient bargaining interest, absent evidence of antiunion animus, to lock out in order to counter union "whipsaw" tactics. ${ }^{162}$

\footnotetext{
1001966 CCH NLRB at 25094.

${ }^{102}$ Western States Regional Council v. NLRB, 365 F.2d 934 (D.C. Cir. 1966). The court of appeals remanded the case to the Board for "findings which give some assurance that [the] ... interpretation of the statute is neither remote nor misty in relation to its factual coordinates." Id. at 939. The court was troubled in two respects with the Weyerhauser decision. First, the Trial Examiner had found that the employers were members of an appropriate multiemployer unit and therefore entitled to lockout under Buffalo Linen. See notes 145-46 supra and accompanying text. The Board, however, instead of considering the appropriateness of the multiemployer unit, noted that the Trial Examiner's opinion preceded American Ship Bldg. and Brown (see notes 150-53, 159 supra and accompanying text) and found those decisions to be controlling. The Board held, therefore, that it was unnecessary to determine whether or not a multiemployer unit did in fact exist, for in either case the employers had acted lawfully. Secondly, the court was apparently disturbed by tbe fact that the General Counsel. of the Board had argued before the Supreme Court in support of the Board's Evening News lockout decision, contending that American Ship Bldg. did not in that case give the employer in one unit the privilege of locking out in support of the bargaining position of the employer in another. See note 153 supra and accompanying text. In view of the foregoing the court concluded that "the Board may or may not be right ... but [its] . . position is, at least, ambiguous." $365 \mathrm{~F} .2 \mathrm{~d}$ at 937.
}

${ }^{109}$ There are indications that the Board in light of American Ship Bldg. and 
Even if it is assumed that former members of a multiemployer unit are held entitled to lock out after a union has withdrawn, the lockout problems presented by Evening News are not entirely solved. The question which immediately arises is whether a union could not, over a period of time after withdrawing from the multiemployer unit, negotiate staggered contract expiration dates with the various employers $^{163}$ and thereby effectively block the use of the lockout by the nonstruck employers. Arguably a union could do so, if it could also negotiate into its collective bargaining agreements the standard clause providing for no lockout by the employer during the contract term. Furthermore, even without such a clause employers might be precluded by staggered contract termination dates from using a bargaining lockout. American Ship Bldg. sanctions lockouts only in support of a legitimate bargaining interest. ${ }^{164}$ Whether nonstruck employers not engaged in negotiations at the same time could lock out thus appears doubtful, especially in light of the Board's recent decision in David Friedland Painting Co., ${ }^{165}$ holding that an employer, although affected economically by the outcome of a labor dispute involving other employers, could not lock out its employees belonging to the union involved, since it "was not in bargaining negotations with the union . . . and therefore was not concerned about advancing its own bargaining position."168

Brown may be compelled to hold that the former members of a multiemployer unit have the right to use a counter-defensive lockout even after union withdrawal. In Detroit Newspaper Publishers Ass'n v. NLRB, 372 F.2d 569 (6th Cir. 1967), for example, the court stated: "We do not say that after withdrawal from the unit the unions could with impunity conduct a whipsaw strike against one of the publishers and that the other would be powerless to exercise its economic weapon of a lockout. ... [W] [Were the lockout is to support an employer's legitimate bargaining position, he could no more be deprived of its use than the right to strike could be taken away from the employees. This . . . is implicit in Buffalo Linen, Brown and American Ship Building." Id. at $\mathbf{5 7 2}$.

${ }^{108}$ The duration of a collective bargaining agreement, as one of the substantive terms of a bargaining agreement, is a matter upon which the parties are required to bargain in good faith. See, e.g., United States Pipe \& Foundry Co. v. NLRB, 298 F.2d 873, cert. denied, 370 U.S. 919 (1962), enforcing sub nom. United Steel Workers, AFL-CIO, I29 N.L.R.B. 357 (1960); Lloyd A. Fry Roofing Co., 123 N.L.R.B. 647 (1959); Hinde \& Dauch Paper Co., 104 N.L.R.B. 847 (1953). Moreover, duration is among those mandatory subjects for bargaining on which neither party is legally obligated to yield. NLRB v. Yutana Barge Lines, Inc., 315 F.2d 524 (9th Cir. 1963); United Steel Workers, AFL-CIO, supra.

106 See note 151 supra and accompanying text.

1031966 CCH NLRB 25841.

${ }^{188}$ Id. at 25843. (Emphasis added.) 
B. The Effect of Unilateral Withdrawal Upon the Stability of Collective Bargaining

Perhaps a more fudamental consideration than employers' lockout rights is the effect of permitting unilateral withdrawal from existing multiemployer bargaining units upon the stability of collective bargaining relations. In formulating rules to govern employer withdrawal from multiemployer units, the Board has concerned itself with preventing the instability which would ensue if the parties at the time of negotiations could not be certain whether a multiemployer unit was appropriate. ${ }^{167}$ It has, therefore, required that employer withdrawal be unequivocally made in writing prior to the commencement of negotiations for a new multiemployer contract. ${ }^{168}$ Since these same requirements are made applicable to union withdrawal under Evening News, ${ }^{169}$ uncertainty as to the appropriate bargaining unit during negotiations should be no greater than that previously existing.

However, a more serious type of instability, namely, increased industrial strife, may result from permitting either party to alter or destroy virtually at will an existing multiemployer unit. Because multiemployer bargaining reduces the resort to economic force in labor relations 170 Congress has recognized it as "a vital factor in the effectuation of the national policy of promoting labor peace . . . "171 By limiting its restrictions on withdrawal from existing multiemployer units to the time and manner of occurrence, the Board has neglected the instability in collective bargaining which may result from the destruction of the multiemployer unit itself.172 It may be that in situations where multiemployer bargaining has not become established, or in those in which it has not been successful in stabilizing collective bargaining between the parties, the imposition of the requirement upon unwilling parties that they continue to utilize the multiemployer device would produce, as the Evening News majority emphasized, "not stability, but friction and instability

\footnotetext{
${ }^{107}$ See notes 70-71 supra and accompanying text.

168 See nates 79-93 supra and accompanying text.

$10^{\circ}$ See note 109 supra and accompanying text.

${ }^{170}$ Witte, Economic Aspects of Industry-Wide Collective Bargaining, in INDUSTRYWide Collectrve Bargatning: Promise or Menace 53 (Warne ed. 1950). See note 2 supra and accompanying text.

${ }^{371}$ NLRB v. Lacal 449, Teamsters Union, 353 U.S. 87, 95 (1957).

${ }^{272}$ See Detroit Newspaper Publishers Ass'n v. NLRB, 372 F.2d 569, 572 (6th Cir. 1967); note 2 supra and accompanying text.
} 
in the bargaining unit."173 On the other hand, it would appear that in those cases where multiemployer bargaining has been especially effective in stabilizing labor relations, or where it is peculiarly adapted to the exigencies of the particular industry, ${ }^{174}$ unilateral destruction of the existing multiemployer unit may well lead to instability in collective bargaining relations. ${ }^{175}$

\section{Conclusion and Recommendations}

The Board's decision in Evening News may well jeopardize the utility of the multiemployer bargaining unit as a stabilizing force in labor relations. ${ }^{176}$ Not only is there the possibility that unions may be able to preclude the use of the Buffalo Linen lockout ${ }^{177}$ by a group of employers, but both the union and the employers now have the right to destroy a successful and stable bargaining relationship without any justification. Moreover, having the right to withdraw unilaterally, both parties, but particularly the union, have a powerful bargaining lever in the mere threat of withdrawal. ${ }^{178}$

Basically, it is the Board's duty to determine in each case the appropriate bargaining unit under section $9(\mathrm{~b})$ of the $\mathrm{act}^{170}$ and to implement the fundamental policy of the act by fostering and maintaining stability in collective bargaining relationships. ${ }^{180}$ Yet by limiting its inquiry in Evening News to whether it should adopt more restrictive rules for union withdrawal than those applicable to employers, the Board has in effect vested in the parties the power to determine the appropriate unit ${ }^{181}$ and has disregarded the resultant

\footnotetext{
2781965 CCH NLRB at 16466.

174 See note 4 supra.

${ }^{278}$ See Detroit Newspaper Publishers Ass'n v. NLRB, 372 F.2d 569, 572 (6th Cir. 1967), enforcing sub nom. Evening News Ass'n, 1965 CCH NLRB 16462; id. at 16467 (dissenting opinion).

176 See authorities cited note 172 supra.

277 See notes 145.66 supra and accompanying text.

${ }^{278}$ Since both employers and unions gain from bargaining on a multiemployer basis (see notes 4-11 supra and accompanying text), the mere threat of unilateral withdrawal may be a potent bargaining weapon. This is especially true of the threat of umion withdrawal, because employers often depend upon multiemployer bargaining to enhance their bargaining power. See notes $4-5$ supra and accompanying text.

${ }^{170}$ See note 15 supra and accompanying text.

${ }^{180}$ See note 143 supra and accompanying text.

181 The Board's willingness to permit unilateral withdrawal from multiemployer units appears inconsistent with its reluctance under its multiemployer unit certification criteria to vest in either party the power to determine the appropriate unit. See notes 26-33 supra and accompanying text.
} 
deleterious effects upon the stability of collective bargaining. ${ }^{182}$ The Board's excessive concern with the consensual nature of multiemployer bargaining ${ }^{183}$ and inequality of treatment of the parties ${ }^{184}$ has precluded it from considering other, perhaps more reasonable, alternatives.

There would appear to be at least two methods by which the Board could have avoided the undesirable consequences of its Evening News decision without considering directly the relative bargaining power of the parties or the economic weapons that should be available to each. One approach would have been for the Board expressly to have adopted new, more restrictive standards for both union and employer withdrawal. ${ }^{185}$ The power of the Board to proceed in this manner in order to maintain and promote stability in collective bargaining is certainly within its "wide administrative discretion"180 and is supported by ample Board precedent.187 The "balancing of conflicting interest" test suggested by Member Brown in his dissent in Evening News, ${ }^{188}$ if applied to both union and employer withdrawal, would appear to be a workable criterion. Under this test the Board would take into consideration the length and character of the multiemployer bargaining history, the nature of employment practices in the industry, common control of or participation in labor relations, the party's reasons for withdrawal, and the instability, if any, that would be likely to result if withdrawal were permitted. The question in each case would be whether under all the circumstances unilateral withdrawal would tend to have such a harmful inpact on the bargaining relationship that it should not be permitted under the stability requirement of the act.

\footnotetext{
${ }^{182}$ See notes $144,167-75$ supra and accompanying text.

${ }^{183}$ See notes 124-33 supra and accompanying text.

184 See notes 118-19, 142 supra and accompanying text.

${ }^{285}$ See note 141 supra and accompanying text.

${ }^{180}$ See note 35 supra.

${ }^{167}$ The purpose of the act to foster and maintain order and stability in industrial relations has been the justification for the Board's present minimal restrictions on withdrawal from multiemployer units. See Quality Limestone Prods., Inc., 1965. CCH NLRB 16086, 16088; Retail Associates, Inc., 120 N.L.R.B. 388, 393-94 (1958); Engineering Metals Prods. Corp., 92 N.L.R.B. 823, 824 (1950); note 73 supra and accompanying text. In imposing more restrictive standards for both union and employer withdrawal "the Board would exercise the same authority which it has in imposing a condition that withdrawals be timely and unequivocal." Detroit Newspaper Pubhishers Ass'n v. NLRB, 372 F.2d 569, 571 (6th Cir. 1967).

${ }^{283} 1965 \mathrm{CCH}$ NLRB at 16469 . The balancing of conficting interest articulation of the Board's function finds support in NLRB v. Local 449, Teamsters Union, 353 U.S. 87, 96 (1957).
} 
The Board could have accomplished substantially the same result by more broadly interpreting its traditional requirement that withdrawal be "unequivocal" and in "good faith"180 to prohibit unilateral withdrawal from existing multiemployer units when made for ulterior motives not related to an honest or genuine desire to forego "with relative permanence" bargaining on a multiemployer basis. ${ }^{100}$ Thus, withdrawal used merely as a momentary bargaining strategy, or to avoid a defensive lockout, would be ineffective as equivocal and not in good faith. Such a holding would not appear to be a great departure, if any, from available precedent; for the Board in several cases has indicated that withdrawal will not be permitted if used merely as a measure of "momentary expedience, or strategy in bargaining." 191

In applying either of the foregoing tests the Board would neither abdicate its authority to determine the appropriate unit, nor ignore the fundamental purpose of the act.

\footnotetext{
${ }^{180}$ See notes 82-86 supra and accompanying text.

200 In Detroit Newspaper Publishers Ass'n v. NLRB, 373 F.2d 569 (6th Cir. 1967), the court stated that "it would seem . . . that the Board could with propriety inquire into the good faith of withdrawals and whether they are harmful to either party, particularly where, as here, the unit has operated satisfactorily for so many years." Id. at 571.

201 See cases cited notes 85.96 supra.
} 